\title{
Risks Associated with the Use of Garcinia as a Nutritional Complement to Lose Weight
}

\author{
Naroa Andueza ${ }^{1}$, Rosa M. Giner ${ }^{2,3}$ and Maria P. Portillo $1,3,4,5, * \mathbb{D}$ \\ 1 Nutrition and Obesity Group, Department of Pharmacy and Food Science, Lucio Lascaray Research Institute, \\ University of the Basque Country (UPV/EHU), 01006 Vitoria, Spain; naroaandueza97@gmail.com \\ 2 Department of Pharmacology, Faculty of Pharmacy, University of Valencia, 46100 Burjassot, Spain; \\ Rosa.M.Giner@uv.es \\ Spanish Agency of Food Safety and Nutrition (AESAN), 28014 Madrid, Spain \\ 4 Bioaraba Health Research Institute, 01009 Vitoria, Spain \\ 5 CIBEROBN Physiopathology of Obesity and Nutrition, Institute of Health Carlos III, 01006 Vitoria, Spain \\ * Correspondence: mariapuy.portillo@ehu.eus; Tel.: +34-945013067; Fax: +34-945013014
}

check for

updates

Citation: Andueza, N.; Giner, R.M.; Portillo, M.P. Risks Associated with the Use of Garcinia as a Nutritional Complement to Lose Weight. Nutrients 2021, 13, 450. https:// doi.org/10.3390/nu13020450

Academic Editor: Antonella Amato

Received: 4 December 2020

Accepted: 24 January 2021

Published: 29 January 2021

Publisher's Note: MDPI stays neutral with regard to jurisdictional claims in published maps and institutional affiliations.

Copyright: (c) 2021 by the authors. Licensee MDPI, Basel, Switzerland. This article is an open access article distributed under the terms and conditions of the Creative Commons Attribution (CC BY) license (https:// creativecommons.org/licenses/by/ $4.0 /)$.

\begin{abstract}
Nowadays, obesity is one of the great nutritional problems facing public health. The prevalence of this pathology has increased in a worrying way over recent years, currently reaching epidemic proportions. In this context, nutritional supplements are presented as a therapeutic alternative to which more and more people are turning to. Nutritional supplements to lose weight based on the Garcinia plant, specifically on Garcinia cambogia, are commonly used. The active principle of this plant to which these properties have been attributed, is hydroxycitric acid (HCA). The aim of the present review is to gather reported data concerning the effectiveness of nutritional supplements based on Garcinia extracts on weight loss and their possible negative effects. Contradictory results have been observed regarding the effectiveness of the supplements. While statistically significant weight loss was observed in some studies, no changes were found in others. Regarding safety, although Garcinia supplements have been revealed as safe in the vast majority of the studies carried out in animal models and humans, some cases of hepatotoxicity, serotonin toxicity and mania have been reported. In conclusion, the results suggest that Garcinia-based supplements could be effective in short-term weight loss, although the data are not conclusive. In addition, the safety of the complement should be further studied.
\end{abstract}

Keywords: Garcinia cambogia; nutritional supplements; weight loss; hepatotoxicity; serotonin toxicity

\section{Introduction}

Obesity is one of the most common nutritional problems worldwide, currently reaching epidemic proportions. This pathology was previously considered typical in developed countries, but nowadays it also shows a high prevalence in underdeveloped countries. According to figures from the World Health Organization (WHO), in 2019 more than 1.9 billion adults aged $\geq 18$ years were overweight, and of them more than 650 million were obese [1]. Since 1975 the worldwide prevalence of obesity has tripled, thus leading to a major public health problem. Obesity is associated with a large number of comorbidities, such as type 2 diabetes mellitus, hypertension, dyslipidemia, non-alcoholic fatty liver disease and cardiovascular diseases, among others. Furthermore, according to the WHO, people with obesity have a 50 to $150 \%$ increased risk of death from any cause compared to individuals with normal weight [2].

Hypocaloric diets and physical activity based treatments for overweight and obesity represent the first line of therapy. Due to the difficulty in achieving and maintaining an adequate adherence to this treatment, many people often turn to nutritional supplements that promise to help them lose weight in the short run or at least, to maintain it. For many people it is an easy solution, which enables them not to modify their lifestyle too much. In 
many instances, the motivation for the use of these supplements is due to aesthetic reasons, since the beauty standards that mark our society today encompass being slim.

These supplements work through five basic mechanisms, these being stimulation of thermogenesis, reduction in lipogenesis, increase in lipolysis, suppression of appetite, and decrease in lipid absorption. Among these nutritional supplements we find those based on plant extracts, which have been used for many centuries in the Eastern world. Nowadays, their use has become more and more prevalent throughout the world. Among them, Garcinia cambogia is one of the most promoted as a potential anti-obesity agent and has received a lot of attention in the media [3].

Although the current consumption of herbs and dietary supplements is unknown, in a study carried out in six European countries, it was estimated that $18.8 \%$ of the 2358 consumers selected for the study consumed one or more dietary supplements, not taking into account herbal products. The percentages of plant food supplement consumers were 9.6\% in Finland, $16.9 \%$ in Germany, $22.7 \%$ in Italy, $17.9 \%$ in Romania, $18.0 \%$ in Spain and $19.1 \%$ in the United Kingdom [4].

The aim of this review is to gather the reported information concerning both the effectiveness and the side-effects of nutritional supplements based on Garcinia cambogia to promote weight loss. In addition, the efficacy of other Garcinia species is also presented. For this purpose, a selective literature search in PubMed and Cochrane databases was performed. To search for the effects on body weight loss, the terms Garcinia, HCA, weight loss, fat mass and obesity were introduced, adding "and", "or", "not" to improve the classification. In addition, the filters "clinical trial" and "meta-analysis" were used. To search for toxic effects, the terms Garcinia, HCA and toxic effects were used. In the Cochrane Library database we sought the term "Garcinia" in the title or the abstract in meta-analyses and clinical trials. The search was extended to a total of 25 years (Figure 1).

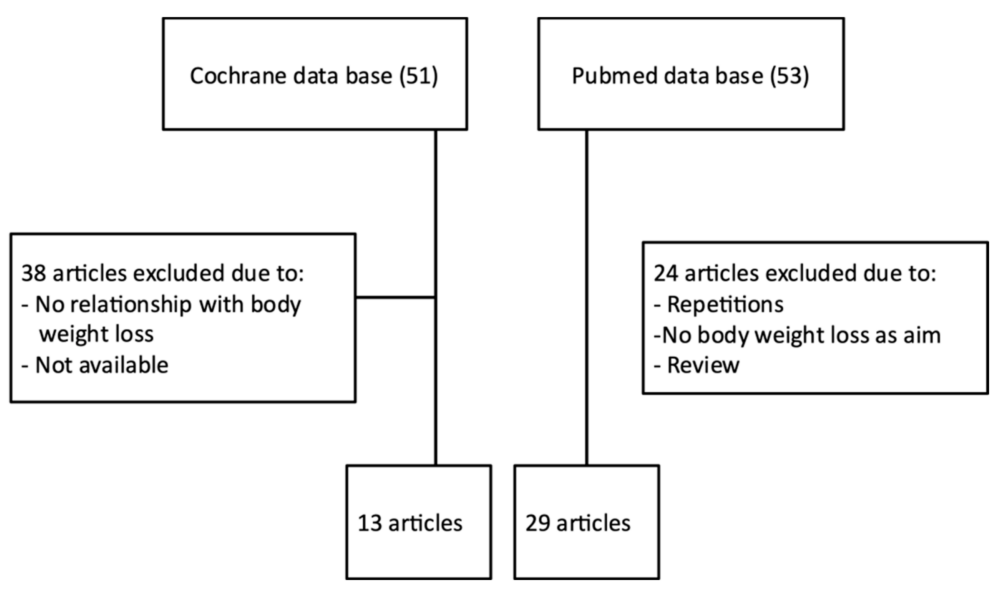

Figure 1. Flow chart showing the process for the inclusions of articles.

\section{Active Principle and Mechanisms of Action}

The genus Garcinia, native to Asia and Africa, belongs to the Clusiaceae family and includes more than 300 species, such as Garcinia cambogia (Figure 2), Garcinia mangostana and Garcinia atroviridis [5]. Potential therapeutic effects, such as anti-obesity, anti-ulcerogenic, antioxidant, anti-diabetes, anti-fungal, anti-inflammatory and anti-neoplasic [6], have been attributed to this genus. This has led to multiple investigations by pharmaceutical companies [5]. Some of the bioactive compounds isolated from Garcinia are garcinol, isogarcin, (-)-hydroxycitric acid (HCA), mangostin, and xanthoquimol [6]. It should be noted that out of the species mentioned above, Garcina cambogia is the most used as a nutritional supplement for weight loss or maintenance. The anti-obesity properties have been attributed to HCA, which is present in the rind or epicarp of the fruit and represents 20-30\% of the dry weight [7]. Many food supplements containing HCA are currently marketed for weight reduction. 

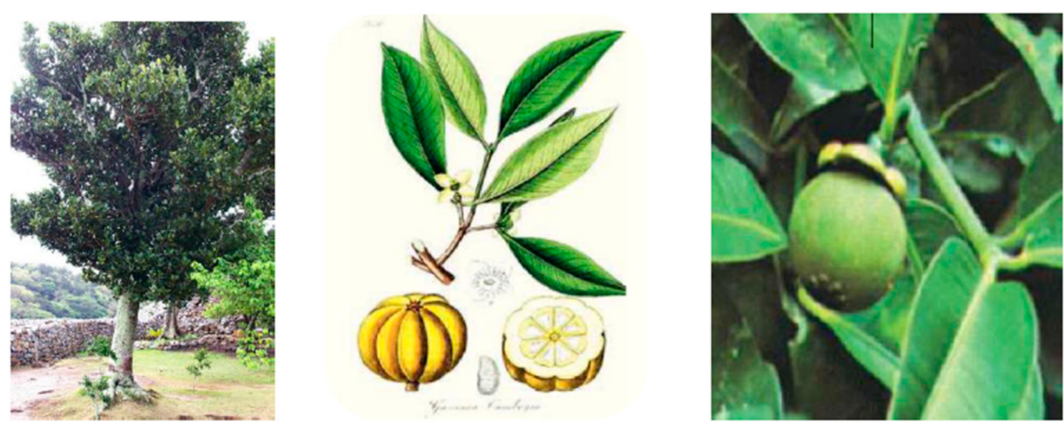

Figure 2. Tree, branch, and fruit of Garcinia cambogia.

The effects of HCA are associated with a reduction in food intake via serotonin level regulation and metabolic modifications, such as an increase in fat oxidation, a decrease in de novo lipogenesis and the stimulation of hepatic glycogenesis, thus promoting energy expenditure. HCA is a competitive inhibitor of adenosine triphosphate (ATP)-citrate lyase, an enzyme that catalyzes the extramitochondrial breakdown of citrate into oxalacetate and acetyl-CoA, thus limiting the availability of acetyl-CoA, a compound that plays a key role in the synthesis of fatty acids in diets rich in carbohydrates (Figure 3).

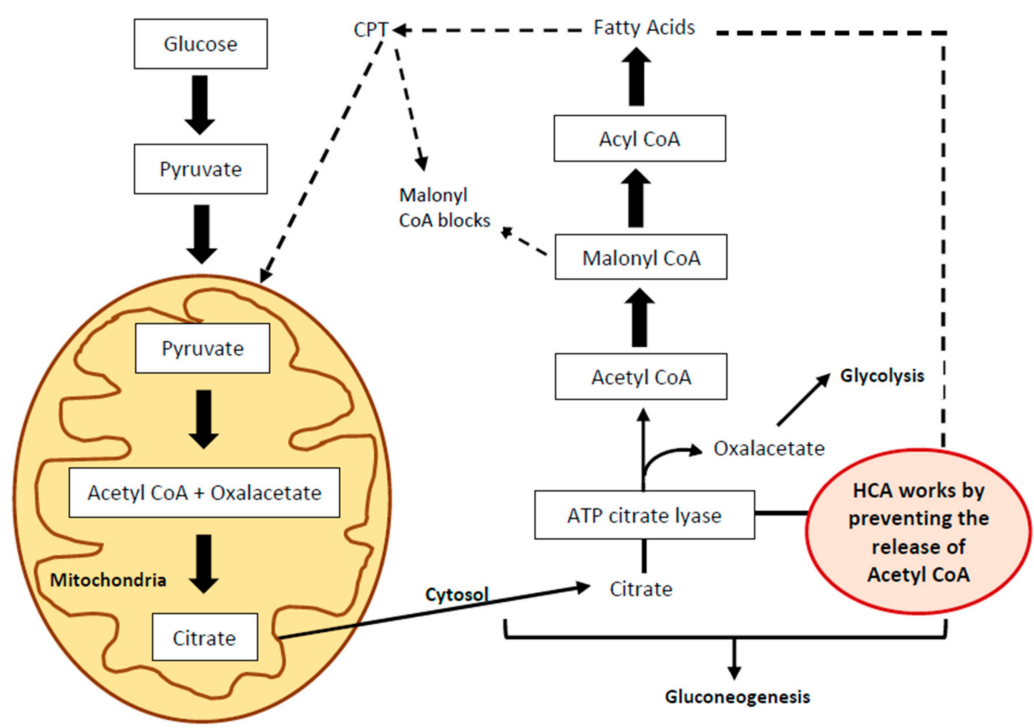

Figure 3. Mechanisms of action of hydroxycitric acid (HCA). CPT: Carnitine palmitoyltransferase.

\section{Effectiveness of Garcinia to Lose and Maintain Body Weight}

In in vitro studies, HCA has been shown to inhibit fatty acid synthesis [8]. Specifically, in isolated hepatocytes, HCA inhibits the synthesis of fatty acids from glucose, but not from acetate. Therefore, HCA is an inhibitor of lipogenesis only if cytoplasmic acetyl-CoA is produced by ATP-citrate lyase. Nevertheless, fatty acid synthesis is able to continue as long as acetate, another acetyl-CoA precursor, is available. As the synthesis of acetyl-CoA is reduced, that of malonyl-CoA is reduced too, thus decreasing the negative feedback of carnitine acyltransferase. This produces an increase in lipid transport in the mitochondria and inefficient oxidation, that promotes the formation of ketone bodies. These molecules can pass into the bloodstream and reach the brain, where they constitute an energy reserve in the event of fasting [8].

In preclinical studies using animal models, chronic oral administration of HCA to rats significantly reduces food intake in the first hour after administration, together with body weight and concentrations of cholesterol, triglycerides and fatty acids. When evaluating the acute and chronic effects of HCA on energy metabolism in mice, it was observed that 
oral administration of $10 \mathrm{mg}$ increased serum concentration of free fatty acids and glycogen concentration in skeletal muscle [9].

Leonhardt et al. (2002) studied the long-term effect of HCA in male Sprague-Dawley rats after a notable body weight loss in two different experiments. Each experiment had 23 or 24 rats, respectively [10]. The rats were fed a $1 \%$ fat diet or a $12 \%$ fat diet, depending on the experiment. Both diets were supplemented with $3 \%$ HCA. HCA produced a long-term reduction in body weight recovery in both groups (in both rats fed $1 \%$ fat or $12 \%$ fat diets). However, only HCA produced a long-term suppressive effect in the case of the group of rats fed the $12 \%$ fat diet. No effect on plasma $\beta$-hydroxybutyrate levels was observed, so the hypothesis that increased fatty acid oxidation in the liver is involved in suppressing food intake by HCA was not supported by these results [11]. In another study, young lean and obese female Zucker rats were fed a diet ( $70 \%$ glucose, $1 \%$ corn oil) supplemented with HCA (52.6 mmol/ $\mathrm{kg}$ diet) for 39 days. Amongst the lean rats, HCA decreased food intake, body weight, the percent of body fat, and fat cell size. Amongst the obese rats, food intake and body weight were lowered, but body fat percentage remained unchanged [10].

In other studies, instead of isolated HCA, extracts of Garcinia were used for supplementation. Saito et al. (2005) studied the ability of a Garcinia cambogia extract, containing HCA, to suppress the accumulation of body fat in growing male obese Zucker rats (6 weeks) [12]. They were given diets containing different amounts of the extract, which provided 10, 51, 102 or $154 \mathrm{mmol}$ of $\mathrm{HCA} / \mathrm{kg}$ of diet, respectively, for 92-93 days. Rats fed the highest amount of extract, and therefore receiving the highest dose of HCA (154 mmol HCA $/ \mathrm{kg}$ diet), significantly decreased epididymal fat accumulation, compared to the other groups.

Table 1 presents a summary of the results obtained in 20 reported intervention studies in humans [13-32]. In 12 studies, statistically significant reductions in body weight were observed $[14,15,18-22,26-28,30,31]$. Conversely, the supplementation turned out to be ineffective in the remaining studies $[13,16,17,23-25,29,32]$. In the studies where significant weight loss was observed, the average value was between 2 and $6 \mathrm{~kg}$ in 2-4 months, with the exception of one where a loss of $14 \mathrm{~kg}$ was induced in 6 months [31]. Interestingly, in 11 studies [19-21,23,24,26,27,29-32], significant reductions in other parameters, such as waist and hip circumference, triglycerides, cholesterol and glucose were also observed regardless of body weight loss. It was specified in the vast majority of the studies that the supplement should be consumed approximately half an hour before meals. Splitting the doses of HCA has also been shown to be more effective than utilizing the same amount given as a single dose.

Table 1. Characteristics and results of published intervention studies in humans.

\begin{tabular}{|c|c|c|c|c|c|c|c|}
\hline \multirow[b]{2}{*}{ Reference } & \multirow[b]{2}{*}{ Type of Study } & \multirow[b]{2}{*}{ Participants } & \multirow[b]{2}{*}{$\begin{array}{c}\text { Diet and Physical } \\
\text { Activity }\end{array}$} & \multirow[b]{2}{*}{ Treatment } & \multirow[b]{2}{*}{$\begin{array}{l}\text { Treatment } \\
\text { Duration }\end{array}$} & \multicolumn{2}{|c|}{ Results } \\
\hline & & & & & & $\begin{array}{l}\text { Weight loss } \\
\text { and Related } \\
\text { Parameters }\end{array}$ & $\begin{array}{l}\text { Other Results } \\
\text { Observed after } \\
\text { the Intervention }\end{array}$ \\
\hline $\begin{array}{l}\text { Heymsfield } \\
\text { et al., } 1998 \text { [13] }\end{array}$ & $\begin{array}{l}\text { Randomized, } \\
\text { double-blind, } \\
\text { placebo- } \\
\text { controlled } \\
\text { study. }\end{array}$ & $\begin{array}{c}135 \text { subjects } \\
\text { BMI } 27-38 \\
\text { aged } 18 \text { to } \\
65 \text { years. } \\
\text { Control: } 69 \\
\text { Intervention: } 66 .\end{array}$ & $\begin{array}{c}1200 \mathrm{Kcal} / \mathrm{d} \text { diethigh in } \\
\text { fibre: } \\
\text {-Proteins: } 30 \% \\
\text {-Lipids: } 20 \% \\
\text {-Carbohydrates: } 50 \% \\
\text { Regular physical } \\
\text { activity }\end{array}$ & $\begin{array}{c}\text { Pills: } 500 \mathrm{mg} \\
\text { Garcinia cambogia } \\
\text { (50\% HCA), } 2 \\
\text { pills, } \\
3 \text { times/day }\end{array}$ & 3 months & $\begin{array}{l}\text { No significant } \\
\text { differences. }\end{array}$ & \\
\hline $\begin{array}{l}\text { Mattes et al., } \\
2000[14]\end{array}$ & $\begin{array}{l}\text { Double-blind, } \\
\text { placebo- } \\
\text { controlled } \\
\text { parallel group } \\
\text { study. }\end{array}$ & $\begin{array}{l}89 \text { women mean } \\
\text { BMI of } 28.6 \text { aged } \\
18 \text { to } 65 \text { years. } \\
\text { Control: } 42 \\
\text { Intervention: } 47\end{array}$ & $\begin{array}{l}1200 \mathrm{Kcal} / \text { diet ( } 30 \% \\
\text { lipids) Exercise was } \\
\text { encouraged, but no } \\
\text { formal regimen was } \\
\text { prescribed. }\end{array}$ & $\begin{array}{l}\text { Capsules: } 400 \\
\text { mg of Garcinia } \\
\text { cambogia (50\% } \\
\text { HCA), } \\
3 \text { times/day }\end{array}$ & 3 months & $\begin{array}{c}\text { Significant } \\
\text { weight loss. } \\
\text { Reduction in } \\
\text { waist } \\
\text { circumference. }\end{array}$ & \\
\hline $\begin{array}{l}\text { Thom et al., } \\
2000 \text { [15] }\end{array}$ & $\begin{array}{l}\text { Randomized } \\
\text { double-blind } \\
\text { study }\end{array}$ & $\begin{array}{c}40 \text { subjects } \\
\text { BMI } 27.5-39.0 \\
\text { aged } \geq 18 \text { years. } \\
\text { Control: } 20 \\
\text { Intervention: } 20 \text {. }\end{array}$ & $\begin{array}{l}\text { Participants were given } \\
\text { diet lists with advice on } \\
\text { low-fat foods, } \\
\text { supplying an energy } \\
\text { intake of approximately } \\
1200 \mathrm{Kcal} / \mathrm{d} \text {, and were } \\
\text { recommended to use } \\
\text { this diet during the } \\
\text { study. }\end{array}$ & $\begin{array}{c}\text { Suco-Blo }{ }^{\mathrm{TM}} \\
\text { (tablets): } 200 \mathrm{mg} \\
\text { Phaseolus vulgaris } \\
\text { extract, } 200 \mathrm{mg} \\
\text { inulin and } 50 \mathrm{mg} \\
\text { Garcinia cambogia } \\
\text { extract } \\
3 \text { times/day. }\end{array}$ & 3 months & $\begin{array}{c}\text { Significant } \\
\text { reductionin } \\
\text { body weight } \\
\text { andbody mass. }\end{array}$ & \\
\hline
\end{tabular}


Table 1. Cont.

\begin{tabular}{|c|c|c|c|c|c|c|c|}
\hline \multirow[b]{2}{*}{ Reference } & \multirow[b]{2}{*}{ Type of Study } & \multirow[b]{2}{*}{ Participants } & \multirow[b]{2}{*}{$\begin{array}{c}\text { Diet and Physical } \\
\text { Activity }\end{array}$} & \multirow[b]{2}{*}{ Treatment } & \multirow[b]{2}{*}{$\begin{array}{l}\text { Treatment } \\
\text { Duration }\end{array}$} & \multicolumn{2}{|c|}{ Results } \\
\hline & & & & & & $\begin{array}{l}\text { Weight loss } \\
\text { and Related } \\
\text { Parameters }\end{array}$ & $\begin{array}{l}\text { Other Results } \\
\text { Observed after } \\
\text { the Intervention }\end{array}$ \\
\hline $\begin{array}{l}\text { Kovacs et al., } \\
2001 \text { [16] }\end{array}$ & $\begin{array}{c}\text { Double-blind, } \\
\text { placebo- } \\
\text { controlled, } \\
\text { randomized, and } \\
\text { cross-over study. }\end{array}$ & $\begin{array}{c}11 \text { obese men } \\
\text { mean BMI of } \\
27.4 \text { mean age of } \\
47 \text { years. }\end{array}$ & $\begin{array}{l}\text { Diet was divided in } \\
3 \text { meals without } \\
\text { restrictions on the type } \\
\text { and quantity of food } \\
\text { and a maximum of one } \\
\text { glass of alcohol drink } \\
\text { per day. }\end{array}$ & $\begin{array}{c}\text { Isoenergetic } \\
\text { snack (cereal } \\
\text { bar): } 4 \text { times/d } \\
\text { Intervention } \\
\text { 1:500 mg HCA } \\
\text { Intervention } \\
\text { 2:500 mg HCA + } \\
3 \text { g MCT }\end{array}$ & $\begin{array}{c}3 \\
\text { Intervention } \\
\text { periods of } 2 \\
\text { weeks } \\
\text { separated by } \\
\text { washout } \\
\text { periods of } \\
4 \text { weeks. }\end{array}$ & $\begin{array}{l}\text { No significant } \\
\text { differences. }\end{array}$ & \\
\hline $\begin{array}{l}\text { Kovacs et al., } \\
2001 \text { [17] }\end{array}$ & $\begin{array}{l}\text { Double-blind, } \\
\text { placebo- } \\
\text { controlled, } \\
\text { randomized, and } \\
\text { crossover study. }\end{array}$ & $\begin{array}{c}21 \text { obese subjects } \\
\text { mean BMI of } 27 \\
\text { mean of age } \\
43 \text { years. }\end{array}$ & $\begin{array}{l}\text { Diet was divided in } \\
3 \text { meals without } \\
\text { restrictions on the type } \\
\text { and quantity of food } \\
\text { and a maximum of one } \\
\text { glass of alcoholic drink } \\
\text { per day. }\end{array}$ & $\begin{array}{c}\text { Isoenergetic } \\
\text { snack (cereal } \\
\text { bar): } 4 \text { times/d } \\
\text { Control: no } \\
\text { supplementation } \\
\text { Intervention } \\
\text { 1:500 mg HCA } \\
\text { Intervention } \\
\text { 2:500 mg HCA + } \\
3 \mathrm{~g} \mathrm{MCT}\end{array}$ & $\begin{array}{c}3 \\
\text { intervention } \\
\text { periods of } 2 \\
\text { weeks } \\
\text { separated by } \\
\text { washout } \\
\text { periods of } 2 \\
\text { or } 6 \text { weeks }\end{array}$ & $\begin{array}{l}\text { No significant } \\
\text { differences. }\end{array}$ & \\
\hline $\begin{array}{c}\text { Hayamizu } \\
\text { et al., } 2003 \text { [18] }\end{array}$ & $\begin{array}{l}\text { Double blind, } \\
\text { randomized, } \\
\text { placebo- } \\
\text { controlled, } \\
\text { parallel-group } \\
\text { study. }\end{array}$ & $\begin{array}{c}44 \text { subjects } \\
\text { aged } 20 \text { to } \\
65 \text { years } \\
\text { visceral fat area } \\
>90 \mathrm{~cm}^{2} \\
\text { Control: } 21 \\
\text { Intervention: } 23\end{array}$ & $\begin{array}{l}\text { Maximun } 2250 \mathrm{Kcal} / \mathrm{d} \\
\text { for men and } \\
1800 \mathrm{Kcal} / \mathrm{d} \text { for women. }\end{array}$ & $\begin{array}{c}\text { Tablets: } \\
185.25 \text { mg of } \\
\text { Garcinia cambogia } \\
\text { extract }(60 \% \\
\text { HCA) } 3 \text { tablets } \\
\text { before each meal } \\
\text { (9 tablets/day) }\end{array}$ & $\begin{array}{l}3 \text { months }+1 \\
\text { month of } \\
\text { placebo in } \\
\text { both groups } \\
\text { at the end. }\end{array}$ & $\begin{array}{l}\text { Reduction in } \\
\text { visceral fat area, } \\
\text { subcutaneous } \\
\text { fat area and } \\
\text { total fat area. }\end{array}$ & \\
\hline $\begin{array}{l}\text { Preuss et al., } \\
2004 \text { [19] }\end{array}$ & $\begin{array}{l}\text { Randomized, } \\
\text { double-blind, } \\
\text { placebo- } \\
\text { controlled } \\
\text { study. }\end{array}$ & $\begin{array}{c}30 \text { subjects } \\
\text { BMI > 26 } \\
\text { aged } 21 \text { to } 50 \\
\text { years } \\
\text { Control:10 } \\
\text { Intervention 1:10 } \\
\text { Intervention 2:10 }\end{array}$ & $\begin{array}{c}2000 \text { Kcal/d divided in } \\
3 \text { meals: } \\
\text { - Proteins: } 17 \% \\
\text { - Lipids: } 25 \% \\
\text { - Carbohydrates: } 58 \% \\
30 \text { min supervised } \\
\text { walking exercise } \\
\text { program ( } 5 \text { days a } \\
\text { week). }\end{array}$ & $\begin{array}{c}\text { HCA-SX ( } 4667 \\
\text { mg) divided in } 3 \\
\text { doses: } \\
\text { Intervention } \\
\text { 1:2800 mg/d of } \\
\text { HCA } \\
\text { Intervention } \\
\text { 2:2800 mg/d of } \\
\text { HCA, } 4 \mathrm{mg} \\
\text { niacin-bound } \\
\text { chromium and } \\
400 \text { mg Gymnema } \\
\text { sylvestre extract. }\end{array}$ & 2 months & $\begin{array}{c}\text { Significant } \\
\text { weight loss in } \\
\text { both } \\
\text { intervention } \\
\text { groups. } \\
\text { Reduction in } \\
\text { food intake. }\end{array}$ & $\begin{array}{l}\text { Reduction in } \\
\text { total cholesterol, } \\
\text { LDL-c, TG, and } \\
\text { leptin levels. } \\
\text { Increase in fat } \\
\text { oxidation, HDL } \\
\text { levels and } \\
\text { serotonin levels. }\end{array}$ \\
\hline $\begin{array}{l}\text { Preuss et al., } \\
2004 \text { [20] }\end{array}$ & $\begin{array}{l}\text { Randomized, } \\
\text { double-blind, } \\
\text { placebo- } \\
\text { controlled } \\
\text { study. }\end{array}$ & $\begin{array}{c}60 \text { subjects } \\
\text { BMI > } 26 \text { aged } 21 \\
\text { to } 50 \text { years } \\
\text { Control: } 20 \\
\text { Intervention 1:20 } \\
\text { Intervention } 2: 20\end{array}$ & $\begin{array}{c}2000 \mathrm{Kcal} / \mathrm{d} \\
\text { - Proteins: } 17 \% \\
\text { - Lipids: } 25 \% \\
\text { - Carbohydrates: } 58 \% \\
30 \text { min supervised } \\
\text { walking exercise } \\
\text { program (5 days a } \\
\text { week). }\end{array}$ & $\begin{array}{c}\text { HCA-SX (4667 } \\
\text { mg) divided in } 3 \\
\text { doses: } \\
\text { Intervention } \\
\text { 1:2800 mg/d of } \\
\text { HCA } \\
\text { Intervention } \\
\text { 2:2800 mg/d of } \\
\text { HCA, } 4 \mathrm{mg} \\
\text { niacin-bound } \\
\text { chromium and } \\
400 \text { mg Gymnema } \\
\text { sylvestre extract. }\end{array}$ & 2 months & $\begin{array}{l}\text { Significant } \\
\text { weight lossand } \\
\text { reduction in } \\
\text { food intake in } \\
\text { both } \\
\text { intervention } \\
\text { groups. }\end{array}$ & $\begin{array}{l}\text { Reduction in } \\
\text { total cholesterol, } \\
\text { LDL-c, TG and } \\
\text { serum leptin } \\
\text { levels in both } \\
\text { intervention } \\
\text { groups. Increase } \\
\text { in HDL-c and } \\
\text { excretion of } \\
\text { urinary fat } \\
\text { metabolites in } \\
\text { both } \\
\text { intervention } \\
\text { groups. }\end{array}$ \\
\hline $\begin{array}{l}\text { Roongpisuthipong } \\
\text { et al., } 2007 \text { [21] }\end{array}$ & $\begin{array}{l}\text { Randomized, } \\
\text { double-blind, } \\
\text { placebo- } \\
\text { controlled } \\
\text { study }\end{array}$ & $\begin{array}{c}50 \text { women } \\
\text { BMI } 25-30 \\
\text { aged } 18 \text { to } 75 \\
\text { years } \\
\text { Control: } 25 \\
\text { Intervention: } 25\end{array}$ & $\begin{array}{c}1000 \mathrm{Kcal} / \mathrm{d} \\
\text { - Proteins: } 50 \mathrm{~g} \\
\text { - Fats: } 33 \mathrm{~g} \\
\text { - Carbohydrates: } 125 \mathrm{~g}\end{array}$ & $\begin{array}{l}\text { Sachets: } 1.15 \mathrm{~g} \text { of } \\
\text { Garcinia } \\
\text { artroviridis } \\
\text { (HCA) } \\
3 \text { times/day }\end{array}$ & 2 months & $\begin{array}{c}\text { Significant } \\
\text { weight loss } \\
\text { during the first } \\
4 \text { weeks. } \\
\text { No significant } \\
\text { differences over } \\
\text { the following } 4 \\
\text { weeks. } \\
\text { Decrease in fat } \\
\text { mass, bicipital, } \\
\text { subscapular } \\
\text { and suprailiac } \\
\text { folds and upper } \\
\text { arm } \\
\text { circumference. }\end{array}$ & $\begin{array}{c}\text { Increase in lean } \\
\text { mass and body } \\
\text { water. } \\
\text { Decrease in TG. }\end{array}$ \\
\hline
\end{tabular}


Table 1. Cont.

\begin{tabular}{|c|c|c|c|c|c|c|c|}
\hline \multirow[b]{2}{*}{ Reference } & \multirow[b]{2}{*}{ Type of Study } & \multirow[b]{2}{*}{ Participants } & \multirow[b]{2}{*}{$\begin{array}{c}\text { Diet and Physical } \\
\text { Activity }\end{array}$} & \multirow[b]{2}{*}{ Treatment } & \multirow[b]{2}{*}{$\begin{array}{l}\text { Treatment } \\
\text { Duration }\end{array}$} & \multicolumn{2}{|c|}{ Results } \\
\hline & & & & & & $\begin{array}{l}\text { Weight loss } \\
\text { and Related } \\
\text { Parameters }\end{array}$ & $\begin{array}{c}\text { Other Results } \\
\text { Observed after } \\
\text { the Intervention }\end{array}$ \\
\hline $\begin{array}{l}\text { Toromanyan } \\
\text { et al., } 2007 \text { [22] }\end{array}$ & $\begin{array}{l}\text { Double blind, } \\
\text { randomized, } \\
\text { parallel group, } \\
\text { placebo- } \\
\text { controlled } \\
\text { study. }\end{array}$ & $\begin{array}{c}60 \text { subjects } \\
\text { BMI } 25-44 \\
\text { aged } 25 \text { to } \\
65 \text { years } \\
\text { Control: } 30 \\
\text { Intervention: } 30 .\end{array}$ & $\begin{array}{l}\text { Diet and exercise } \\
\text { performed regularly. }\end{array}$ & $\begin{array}{c}\text { Slim339 } 39 \\
\text { (tablets): } 132 \mathrm{mg} \\
\text { of Garcinia } \\
\text { cambogia (HCA) } \\
\text { + Matricaria } \\
\text { chamomilla, Rosa } \\
\text { damascena, } \\
\text { Lavandula } \\
\text { officinalis and } \\
\text { Cananga odorata } \\
3 \text { times } / \mathrm{d} \text {. }\end{array}$ & 2 months & $\begin{array}{l}\text { Significant } \\
\text { weight } \\
\text { reduction. }\end{array}$ & \\
\hline $\begin{array}{l}\text { Vasques et al., } \\
2008 \text { [23] }\end{array}$ & $\begin{array}{l}\text { Randomized } \\
\text { double-blind } \\
\text { study }\end{array}$ & $\begin{array}{c}58 \text { subjects } \\
\text { BMI } 30-39.9 \\
\text { aged } 25 \text { to } \\
60 \text { years } \\
\text { Control: } 26 \\
\text { Intervention: } 32\end{array}$ & & $\begin{array}{l}\text { Capsules: } 800 \\
\text { mg of Garcinia } \\
\text { cambogia (HCA) } \\
+500 \text { mg de } \\
\text { Amorphophallus } \\
\text { konjac } \rightarrow \\
3 \text { times/day }\end{array}$ & 3 months & $\begin{array}{l}\text { No significant } \\
\text { reduction in } \\
\text { body weight. }\end{array}$ & $\begin{array}{l}\text { Reduction in } \\
\text { total cholesterol } \\
\text { and LDL-c. }\end{array}$ \\
\hline $\begin{array}{l}\text { Kim et al., } \\
2011 \text { [24] }\end{array}$ & $\begin{array}{l}\text { Randomized, } \\
\text { double-blind, } \\
\text { placebo- } \\
\text { controlled } \\
\text { study }\end{array}$ & $\begin{array}{l}86 \text { subjects } \\
\text { BMI } 23-29 \\
\text { aged } 20 \text { to } \\
60 \text { years. } \\
\text { Control: } 29 \\
\text { Glycine max } \\
\text { leaves (GML): } 28 \\
\text { Garcinia cambogia } \\
\text { (GC): } 29\end{array}$ & $\begin{array}{l}\text { Diet and habitual } \\
\text { physical activity }\end{array}$ & $\begin{array}{l}\text { Pills: } 2 \mathrm{~g} / \mathrm{d} \text { of } \\
\text { the substances } \\
\text { corresponding to } \\
\text { each group. In } \\
\text { the case of the } \\
\text { placebo and } \\
\text { GML } 4 \text { pills/d } \\
\text { and for Garcinia } \\
\text { cambogia } \\
8 \text { pills/day. }\end{array}$ & 2.5 months & $\begin{array}{l}\text { No significant } \\
\text { reduction in } \\
\text { body weight. }\end{array}$ & $\begin{array}{l}\text { GML reduced } \\
\text { total cholesterol } \\
\text { and increased } \\
\text { HDL-c } \\
\text { (significant } \\
\text { differences } \\
\text { compared to the } \\
\text { placebo group } \\
\text { and the GC and } \\
\text { placebo group, } \\
\text { respectively). }\end{array}$ \\
\hline $\begin{array}{c}\text { Lu et al., } 2012 \\
{[25]}\end{array}$ & $\begin{array}{l}\text { Randomized } \\
\text { double-blind } \\
\text { study }\end{array}$ & $\begin{array}{l}114 \text { overweight } \\
\text { subjects }\end{array}$ & Nutritional education & $\begin{array}{c}\text { Super CitriMax }{ }^{\mathrm{TM}} \\
\text { (HCA) } \\
2800 \mathrm{mg} / \text { day }\end{array}$ & 2 months & $\begin{array}{l}\text { No significant } \\
\text { reduction in } \\
\text { body weight. }\end{array}$ & \\
\hline $\begin{array}{l}\text { Stern et al., } \\
2013 \text { [26] }\end{array}$ & $\begin{array}{l}\text { Randomized, } \\
\text { double-blind, } \\
\text { placebo- } \\
\text { controlled } \\
\text { clinical study }\end{array}$ & $\begin{array}{c}60 \text { subjects } \\
\text { BMI } 30-40 \\
\text { aged } 21 \text { to } \\
50 \text { years } \\
\text { Control: } 30 \\
\text { Intervention: } 30\end{array}$ & $\begin{array}{l}\text { Participants were given } \\
\text { free prepared meals. } \\
2000 \text { Kcal/d } \\
\text { - Proteins: } 14 \% \\
\text { - Lipids: } 25 \% \\
\text { - Carbohydrates: } 61 \% \\
\text { Physical activity } \\
\text { (walking) } 30 \\
\text { min, } 5 \text { times } / \mathrm{d} \text {. }\end{array}$ & $\begin{array}{c}\text { Capsules: } 400 \\
\text { mg of } \\
\text { Sphaeranthus } \\
\text { indicus + Garcinia } \\
\text { mangostana, ratio } \\
\text { 3:1 2 times/day }\end{array}$ & 2 months & $\begin{array}{l}\text { Significant } \\
\text { reduction in } \\
\text { body weight, } \\
\text { BMI and waist } \\
\text { circumference. }\end{array}$ & $\begin{array}{c}\text { Decrease in total } \\
\text { cholesterol and } \\
\text { TG and increase } \\
\text { in adiponectin. }\end{array}$ \\
\hline $\begin{array}{l}\text { Stern et al., } \\
2013 \text { [27] }\end{array}$ & $\begin{array}{l}\text { Randomized, } \\
\text { double-blind, } \\
\text { placebo- } \\
\text { controlled } \\
\text { clinical study }\end{array}$ & $\begin{array}{c}95 \text { subjects } \\
\text { BMI } 30-40 \\
\text { aged } 36 \text { to } \\
40 \text { years } \\
\text { Control: } 46 \\
\text { Intervention: } 49\end{array}$ & $\begin{array}{c}\text { Same diet } \\
\text { and physical activityas } \\
\text { in reference } 26 . \\
\text { In this case the diet is } \\
\text { divided into } 3 \text { intakes. }\end{array}$ & $\begin{array}{l}\text { Same treatment } \\
\text { as in } \\
\text { reference } 26 .\end{array}$ & 2 months & $\begin{array}{l}\text { Reduction in } \\
\text { body weight, } \\
\text { BMI, waist and } \\
\text { hip circumferences. }\end{array}$ & $\begin{array}{c}\text { Decrease in total } \\
\text { cholesterol, TG } \\
\text { and fasting } \\
\text { glucose. Increase } \\
\text { in adiponectin. } \\
\text { Improvement in } \\
\text { physical function } \\
\text { and self-esteem } \\
\text { (IWQOL } \\
\text { questionnaire). }\end{array}$ \\
\hline $\begin{array}{l}\text { Chong et al., } \\
2014 \text { [28] }\end{array}$ & $\begin{array}{l}\text { Randomized, } \\
\text { placebo- } \\
\text { controlled, } \\
\text { double-blind } \\
\text { parallel group } \\
\text { study }\end{array}$ & $\begin{array}{l}91 \text { caucasian } \\
\text { subjects } \\
\text { BMI } 25-32 \\
\text { aged } 18 \text { to } \\
60 \text { years } \\
\text { Control: } 45 \\
\text { Intervention: } 46\end{array}$ & $\begin{array}{c}\text { Dietary advice }+ \\
\text { balanced diet with a } \\
\text { deficit of } 500 \text { Kcal. } \\
-30 \% \text { lipids. }\end{array}$ & $\begin{array}{c}\text { Tablets: } 850 \mathrm{mg} \\
3 \text { tablets } \\
2 \text { times/day. } \\
\text { Composition: } \\
650 \mathrm{mg} \text { of } \\
\text { Garcinia cambogia } \\
\text { (HCA) }+100 \mathrm{mg} \\
\text { of Camellia } \\
\text { sinensis }+75 \mathrm{mg} \\
\text { of Coffea arabica }+ \\
25 \mathrm{mg} \text { of } \\
\text { Lagerstroemia } \\
\text { speciosa }\end{array}$ & 3.5 months & $\begin{array}{l}\text { Significant } \\
\text { weight loss and } \\
\text { reduction in } \\
\text { BMI, body fat, } \\
\text { waist and hip } \\
\text { circumferences }\end{array}$ & \\
\hline
\end{tabular}


Table 1. Cont.

\begin{tabular}{|c|c|c|c|c|c|c|c|}
\hline \multirow[b]{2}{*}{ Reference } & \multirow[b]{2}{*}{ Type of Study } & \multirow[b]{2}{*}{ Participants } & \multirow[b]{2}{*}{$\begin{array}{c}\text { Diet and Physical } \\
\text { Activity }\end{array}$} & \multirow[b]{2}{*}{ Treatment } & \multirow[b]{2}{*}{$\begin{array}{l}\text { Treatment } \\
\text { Duration }\end{array}$} & \multicolumn{2}{|c|}{ Results } \\
\hline & & & & & & $\begin{array}{c}\text { Weight loss and } \\
\text { Related } \\
\text { Parameters }\end{array}$ & $\begin{array}{l}\text { Other Results } \\
\text { Observed after } \\
\text { the Intervention }\end{array}$ \\
\hline $\begin{array}{l}\text { Vasques et al., } \\
2014 \text { [29] }\end{array}$ & $\begin{array}{l}\text { Randomized } \\
\text { double-blind } \\
\text { study }\end{array}$ & $\begin{array}{c}43 \text { women } \\
\text { BMI > 25) } \\
\text { aged } 25 \\
\text { to } 60 \text { years } \\
\text { Control: } 13 \\
\text { Intervention: } 30\end{array}$ & $\begin{array}{c}\text { Individualized diet, } \\
\text { with an average caloric } \\
\text { restriction of } \\
1523 \pm 185 \mathrm{Kcal} / \text { day } \\
\text { Regular physical } \\
\text { activity. }\end{array}$ & $\begin{array}{l}\text { Capsules: } 800 \\
\text { mg of Garcinia } \\
\text { cambogia (HCA) } \\
3 \text { times/day }\end{array}$ & 2 months & $\begin{array}{l}\text { No statistically } \\
\text { significant } \\
\text { differences. }\end{array}$ & $\begin{array}{c}\text { Reduction in TG } \\
\text { level. }\end{array}$ \\
\hline $\begin{array}{l}\text { Kudiganti } \\
\text { et al., 2016 } \\
{[30]}\end{array}$ & $\begin{array}{c}\text { Randomized, } \\
\text { double-blind, } \\
\text { placebo- } \\
\text { controlled } \\
\text { clinical study }\end{array}$ & $\begin{array}{c}60 \text { subjects } \\
\text { mean BMI of } 28.3 \\
\text { aged } 21 \text { to } \\
50 \text { years } \\
\text { Control: } 30 \\
\text { Intervention: } 30 \text {. }\end{array}$ & $\begin{array}{c}2000 \mathrm{Kcal} / \mathrm{d} \\
\text { - Proteins: } 17 \% \\
\text { - Lipids: } 25 \% \\
\text { - Carbohydrates: } 58 \%\end{array}$ & $\begin{array}{l}\text { Capsules: } \\
400 \text { mg of } \\
\text { Meratrim }{ }^{\mathrm{TM}} \text { : } \\
\text { extracts from the } \\
\text { flower heads of } \\
\text { Sphaeranthus } \\
\text { indicus and the } \\
\text { fruit rinds of } \\
\text { Garcinia } \\
\text { mangostana } \\
2 \text { times/day }\end{array}$ & 4 months & $\begin{array}{l}\text { Significant } \\
\text { weight loss and } \\
\text { reduction in BMI, } \\
\text { waist and hip } \\
\text { circumferences. }\end{array}$ & $\begin{array}{l}\text { Reduction in TG } \\
\text { and LDL-c } \\
\text { cholesterol. } \\
\text { Increase in } \\
\text { HDL-c. }\end{array}$ \\
\hline $\begin{array}{l}\text { Maia-Landim } \\
\text { et al., } 2018 \\
\text { [31] }\end{array}$ & $\begin{array}{l}\text { Non- } \\
\text { randomized } \\
\text { prospective } \\
\text { controlled } \\
\text { intervention } \\
\text { study }\end{array}$ & $\begin{array}{l}214 \text { subjects } \\
\text { BMI > } 25 \\
\text { older than } \\
18 \text { years }\end{array}$ & $\begin{array}{l}\text { Balanced diet and } \\
\text { regular physical activity, } \\
\text { smoking not permitted } \\
\text { and controlof alcohol } \\
\text { intake. }\end{array}$ & $\begin{array}{c}\text { Capsules: } 500 \\
\text { mg of } \\
\text { Garcinia cambogia } \\
\text { (HCA) }+ \\
500 \mathrm{mg} \text { of } \\
\text { Amorphophallus } \\
\text { konjac } \\
2 \text { times/day }\end{array}$ & 6 months & $\begin{array}{l}\text { Reduction in } \\
\text { total fat mass } \\
\text { and visceral fat } \\
\text { mass after } 3 \text { and } \\
6 \text { months of } \\
\text { intervention. }\end{array}$ & $\begin{array}{c}\text { Increase in basal } \\
\text { metabolic rate } \\
\text { Reduction in } \\
\text { glucose, total } \\
\text { cholesterol and } \\
\text { TG. }\end{array}$ \\
\hline $\begin{array}{c}\text { Watanabe } \\
\text { et al., 2018 } \\
\text { [32] }\end{array}$ & $\begin{array}{l}\text { Prospective, } \\
\text { randomized, } \\
\text { controlled, } \\
\text { parallel study }\end{array}$ & $\begin{array}{l}22 \text { obese women } \\
\text { with insulin } \\
\text { resistance } \\
\text { aged } 18 \text { to } \\
65 \text { years } \\
\text { Control: } 11 \\
\text { Intervention: } 11\end{array}$ & $\begin{array}{c}\text { Hypocaloric diet (300 } \\
\text { Kcal restriction) + } \\
\text { physical activity of } \\
\text { moderate intensity } \\
\text { - Proteins: } 20-25 \% \\
\text { - Lipids: } 30 \% \\
\text { - Carbohydrates: } \\
45-50 \%\end{array}$ & $\begin{array}{l}\text { Capsules: } 400 \\
\text { mg of Garcinia } \\
\text { mangostana } 1 \\
\text { time/day }\end{array}$ & 6.5 months & $\begin{array}{l}\text { No significant } \\
\text { reduction in } \\
\text { body weight. }\end{array}$ & $\begin{array}{l}\text { Reduction in } \\
\text { insulin } \\
\text { concentration } \\
\text { and HOMA-IR. }\end{array}$ \\
\hline
\end{tabular}

BMI: body mass index; HCA: hydroxycitric acid; HOMA-IR: insulin resistance index, MCT: medium chain triglyceride; TG: triglycerides; IWQOL: impact of weight on quality of life-lite.

Of note, important differences in the experimental design can be observed among the reported studies. The number of participants ranged from 11 to 214 . The fact that the majority of the studies had a small sample size limits the reliability of the results. In addition, in some cases there is a lack of proportion between men and women. The inclusion of both genders is important in order to determine whether there is sexual dimorphism in the effectiveness of the nutritional supplement. Conversely, in all the selected studies, the participants were overweight or obese (based on body mass index) and the duration of treatments ranged from 2 to 4 months in the majority studies, with the exception of two longer ones, in which the duration was 6 or 6.5 months.

The variability is also observed in the type of supplement administered. Upon that, Garcinia cambogia/HCA was used in 15 studies, Garcinia mangostana in four studies and Garcinia artroviridis in one study. Lastly, in some cases HCA or Garcinia appeared to be combined with other ingredients, such as glucomannan (fiber), Sphaeranthus indicus or Coffea arabica. Consequently, it is not possible to determine whether the effect produced was due to the HCA content, to other ingredients, or to a combination of the effects of the different ingredients. The dose administered is another differential aspect among the studies. Last of all, the presentation of the supplement is different (pills, capsules or sachets). It is indicated in all cases that the supplement should be consumed before the meal (approximately half an hour before).

Differences in other aspects of the experimental design, such as diet and physical activity can also be found. In some studies, the participants were instructed to continue with their usual diet and physical activity, while in others they were given specific instructions. Lastly, in others they were prescribed a hypocaloric diet along with specific practice of regular physical activity. 
Some of these differential aspects could explain the lack of effect observed in several studies, for instance, the lowest sample size in the studies reported by Kovacs et al. (2001) [16], Kovacs et al. (2001) [17] and Watanabe et al. (2018) [32] In the study reported by Heymsfield et al. (1998) [13], Garcinia cambogia was not effective since the diet was low in energy and high in fiber. The amount of fiber could have inhibited the gastrointestinal absorption of HCA (active compound in Garcinia cambogia) and the low energy supplied (approximately $1200 \mathrm{Kcal}$ ) could have affected the usefulness of HCA. In addition, the dose of HCA was lower than that used in other studies. Another parameter that could have an influence was the excess of calcium used to stabilize HCA, that could have reduced the solubility of this bioactive compound, and therefore its bioavailability [8]. In a similar way, the lack of effect in the studies carried out by Roongpisuthipong et al. (2007) [21] and Vasques et al. (2014) [29] could be related to the low amount of energy provided by the diet $(1000 \mathrm{Kcal} / \mathrm{d}$ and $1500 \mathrm{Kcal} / \mathrm{d}$, respectively). In the study conducted by Vasques et al. (2008) [23], the only apparent potential reason could be that neither dieting, nor practicing physical activity were recommended. In contrast, in all the studies in which positive results were obtained, a healthy lifestyle was either prescribed or recommended. Last of all, in the studies conducted by Kim et al. (2011) [24] and Hayamizu et al. (2003) [18], in an Asian population, it is believed that the fact that the fruit of the Garcinia is of common use as part of the traditional diet, could have led to a reduced susceptibility to its effects.

Onakpoya et al. (2011) published a systematic review and meta-analysis of randomized clinical trials devoted to evaluating the effectiveness of Garcinia extracts as weight reduction agents [33]. The authors concluded that these extracts generated short-term weight loss. However, the scale of this effect was small, since it was not statistically significant when only rigorous randomized clinical trials were considered. Therefore, the clinical relevance of these products appears to be questionable and they do not represent an altogether effective measure of the treatment of overweight and obesity.

\section{Negative Effects on Health}

\subsection{Animal Toxicity Studies}

Studies of acute, short-term, sub-chronic, and chronic toxicity, as well as studies of genotoxicity, cytotoxicity and toxicity in reproduction, have been conducted in different animal species, although mainly in rats and rabbits. These studies have shown that Garcinia/HCA have good safety profiles, so that they may be used as nutritional supplements for the treatment of obesity [34-36].

Ohia et al. (2002) evaluated the effects of Super Citri-Max ${ }^{\mathrm{TM}}$, a novel calcium/potassiumHCA extract (HCA-SX), containing 60\% HCA, administered for 14 days. This extract is considerably more soluble and bioavailable than calcium-based HCA ingredients [37]. The study was conducted in Albino rats (males and females) fed ad libitum, treated with a dose of $5000 \mathrm{mg} / \mathrm{kg}$ (through a gastric probe), which is equivalent to $350 \mathrm{~g}$ or 233 times the maximum dose of $1.5 \mathrm{~g} /$ day of HCA in humans. The authors did not report any death or significant clinical changes. Furthermore, no significant tissue injuries were observed during the necropsy, which led them to suggest that the LD50 oral administration of HCA-SX in rats was over $5000 \mathrm{mg} / \mathrm{kg}$. Similarly, in another study carried out by the Wil Research Laboratories, it was shown that $5000 \mathrm{mg}$ HCA $/ \mathrm{kg}$ of body weight did not produce visible symptoms of toxicity or death in animal models. In line with these studies, Clouatre et al. (2013) defended that HCA was extremely safe and this was corroborated by various reviews where it was claimed that HCA from Garcinia cambogia had a protective effect on the liver [38].

Shara et al. (2003) analyzed the effects of HCA intake on weight, testicular and liver lipid peroxidation, and DNA fragmentation, in addition to possible histopathological changes in Sprague-Dawley rats [39]. The animals received 0.2, 2.0, or 5.0\% HCA $(100-2500 \mathrm{mg} / \mathrm{kg}$ ) in their diet, equivalent to approximately 100,1000 , and $2500 \mathrm{mg} / \mathrm{kg} /$ day, respectively, in humans. The lowest dose was equivalent to the daily recommended dosage in humans, but the doses of 2.0 and $5.0 \%$ are 10 to 25 times higher doses. The rats were 
euthanized at 30,60, and 90 days of treatment. After 90 days of HCA administration, rats showed decreased body weight, without changes in liver or testicular lipid peroxidation or in DNA fragmentation In a follow-up study, the same authors did not find differences in the weight of various organs. Moreover, no haematological or biochemical disorders or significant histopathological changes or mortality differences were found [40].

As an exception, Kim et al. (2013) in a study addressed in rats fed a high-fat diet (45\% of total energy), it was shown that after 16 weeks of treatment with Garcinia cambogia (1\%, $w / w, 60 \%$ HCA) oxidative stress, inflammation and liver fibrosis were triggered [41]. Consequently, it appears that the form of HCA regarding its extraction process and the residual compounds, among other factors, may spur differences between study outcomes [42].

Toxicological studies have been also addressed with other Garcinia species. Farombi et al. (2013) carried out a study in adult male Wistar rats randomly assigned to four groups of 10 rats each group given Garcinia kola orally at different doses $(0,250,500$ and $1000 \mathrm{mg} / \mathrm{kg})$ for 6 weeks [43]. After conducting the study, it was concluded that the administration of Garcinia kola increased the antioxidant status and did not produce adverse effects on the liver, testicles and sperm. Saiyed et al. (2015) performed various toxicological studies both in vitro and in animals to evaluate the safety of Meratrim ${ }^{\mathrm{TM}}$, a supplement that contains Garcinia mangostana [44]. Meratrim ${ }^{\mathrm{TM}}$ was determined to be non-irritating to the skin, mildly irritating to the eyes, not mutagenic, and the no-observed-adverse-effect level (NOAEL) for this supplement was $1000 \mathrm{mg} / \mathrm{kg}$ body weight/day (in Sprague-Dawley rats). The authors concluded that the safety of Meratrim was demonstrated given the results observed in this study, added to the clinical trials of tolerability already carried out.

\subsection{Clinical Toxicity}

Based on toxicological studies, Soni et al. (2004) noted that there was sufficient quantitative and qualitative scientific evidence, from both animal and human data, to suggest that HCA intake up to $2800 \mathrm{mg}$ /day is safe for human consumption [35]. As a result, a NOAEL of $2800 \mathrm{mg} / \mathrm{d}$ was established [34,35].

Accordingly, none of the studies included in Table 1, devoted to analyzing the effects of Garcinia on body weight reductions at doses below this value have found serious adverse effects. Some of the minor side effects observed were leg cramps, heartburn, diarrhoea, increased gas, higher appetite, headaches, heartburn, rash, menstrual bleeding, and general weakness. In spite of this, other authors have reported toxic manifestations, including hepatotoxicity, acute pancreatitis, serotonin toxicity and psychosis after the consumption of Garcinia-containing products (either as an extract containing other components or pure). In 16 of the 21 cases described in Table 2 [45-60], these adverse effects have occurred after the intake of formulations which contained other ingredients besides Garcinia. One of these formulations is Hydroxycut ${ }^{\mathrm{TM}}$. Fourteen different products are marketed under this name, but only eight of them contain Garcinia cambogia. In addition, all of them are polyherbal products that can contain up to 20 different substances [34]. When toxic effects are induced by supplements that, in addition to Garcinia, contain other components, it has not been possible to confirm that Garcinia is the agent responsible for the side-effects. In spite of this, the FDA (US Food and Drug Administration) issued a warning in 2009 on Hydroxycut ${ }^{\mathrm{TM}}$ products related to hepatotoxicity, which led to the recall of these products.

Table 2. Cases of liver damage associated with the consumption of Garcinia cambogia supplements in humans.

\begin{tabular}{|c|c|c|c|c|c|c|c|}
\hline Reference & Ageyears & Sex & $\begin{array}{c}\text { Type of } \\
\text { Supplement }\end{array}$ & Duration & Symptoms & Test Performed & $\begin{array}{l}\text { Diagnosis/Type } \\
\text { of Liver Injury }\end{array}$ \\
\hline $\begin{array}{l}\text { Stevens et al., } \\
2005 \text { [45] }\end{array}$ & 27 & M & $\begin{array}{l}\text { Hydroxycut }^{\mathrm{TM}} \\
3 \text { capsules, } \\
3 \text { times } / \mathrm{d} \text {. }\end{array}$ & 5 weeks & Fatigue and jaundice. & $\begin{array}{l}\text { Laboratory analysis: } \\
\text { elevated AST, ALT, AF } \\
\text { and PT. Serological study: } \\
\text { negative. }\end{array}$ & $\begin{array}{l}\text { Hepatotoxicity } \\
\text { Cholestatic } \\
\text { liver injury } \\
\text { pattern. }\end{array}$ \\
\hline
\end{tabular}


Table 2. Cont.

\begin{tabular}{|c|c|c|c|c|c|c|c|}
\hline Reference & Ageyears & Sex & $\begin{array}{c}\text { Type of } \\
\text { Supplement }\end{array}$ & Duration & Symptoms & Test Performed & $\begin{array}{l}\text { Diagnosis/Type } \\
\text { of Liver Injury }\end{array}$ \\
\hline $\begin{array}{l}\text { Stevens et al., } \\
2005 \text { [45] }\end{array}$ & 30 & $\mathrm{M}$ & $\begin{array}{l}\text { Hydroxycut } \\
9 \text { capsules } / \mathrm{d} \text {. }\end{array}$ & 5 days & $\begin{array}{l}\text { Fever, vomiting, } \\
\text { fatigue, and jaundice. }\end{array}$ & $\begin{array}{l}\text { Laboratory analysis: AST, } \\
\text { ALT, AF and PT elevated } \\
\text { and low albumin. } \\
\text { Serological study: } \\
\text { negative. CT and } \\
\text { cholangiography: } \\
\text { normal. }\end{array}$ & $\begin{array}{l}\text { Hepatotoxicity } \\
\text { Hepatocyte } \\
\text { necrosis was } \\
\text { the likely } \\
\text { pattern of } \\
\text { injury. }\end{array}$ \\
\hline $\begin{array}{l}\text { Dara et al., } \\
2008 \text { [46] }\end{array}$ & 40 & W & $\begin{array}{l}\text { Hydroxycut } \\
6 \text { capsules } / \mathrm{d} \text {. }\end{array}$ & 1 week & $\begin{array}{l}\text { Mid-epigastric } \\
\text { abdominal pain, } \\
\text { non-bloody diarrhea, } \\
\text { fevers, chills, nausea, } \\
\text { vomiting, anorexia } \\
\text { and profound } \\
\text { fatigue. }\end{array}$ & $\begin{array}{c}\text { Laboratory analysis: } \\
\text { acute hepatitis (elevated } \\
\text { AST, ALT and AF) } \\
\text { Serological study: } \\
\text { negative. }\end{array}$ & $\begin{array}{c}\text { Acute } \\
\text { hepatitis. }\end{array}$ \\
\hline $\begin{array}{l}\text { Dara et al., } \\
2008 \text { [46] }\end{array}$ & 33 & W & Hydroxycut $^{\mathrm{TM}}$ & 2 weeks & $\begin{array}{l}\text { Nausea, crampy } \\
\text { abdominal pain, } \\
\text { jaundice, acholic } \\
\text { stools, dark-colored } \\
\text { urine, pruritus and } \\
\text { profound fatigue. }\end{array}$ & $\begin{array}{c}\text { Physical examination: } \\
\text { jaundice and scleral } \\
\text { icterus. Laboratory } \\
\text { analysis: elevated AST, } \\
\text { ALT, TB and DB. } \\
\text { Serological study: } \\
\text { negative. }\end{array}$ & $\begin{array}{c}\text { Acute } \\
\text { hepatitis. }\end{array}$ \\
\hline $\begin{array}{l}\text { Shuster et al., } \\
2010 \text { [47] }\end{array}$ & 25 & M & $\begin{array}{l}\text { Exilis: Garcinia } \\
\text { cambogia, } \\
\text { Garcinia } \\
\text { sylvestre, } \\
\text { L-carnintine } \\
\text { and chrome }\end{array}$ & 3 weeks & $\begin{array}{l}\text { Two weeks after } \\
\text { starting treatment: } \\
\text { fatigue and dark } \\
\text { urine. In the third } \\
\text { week: fever, nausea, } \\
\text { vomiting and pain. }\end{array}$ & $\begin{array}{l}\text { Laboratory analysis: } \\
\text { elevated ALT, AST, TB } \\
\text { and INRA } \\
\text { comprehensive study } \\
\text { was conducted to } \\
\text { determine the etiology of } \\
\text { liver damage, but all tests } \\
\text { were negative. }\end{array}$ & $\begin{array}{l}\text { Hepatic en- } \\
\text { cephalopathy } \\
\text { Liver trans- } \\
\text { plantation } \\
\text { required. }\end{array}$ \\
\hline $\begin{array}{l}\text { Sharma et al., } \\
2010 \text { [48] }\end{array}$ & 19 & $\mathrm{M}$ & Hydroxycut $^{\mathrm{TM}}$ & 1 week & $\begin{array}{l}\text { Fever, severe fatigue, } \\
\text { myalgia, arthralgia, } \\
\text { and erythematous } \\
\text { rash over in lower } \\
\text { extremities. }\end{array}$ & $\begin{array}{l}\text { Physical examination: } \\
\text { toxic appearance, marked } \\
\text { jaundice and fever } \\
\left(39.4^{\circ} \mathrm{C}\right) \text {. Laboratory } \\
\text { analysis: elevated ALT, } \\
\text { AF, bilirubin and PT. low } \\
\text { blood cell count and } \\
\text { hemoglobin. Blood } \\
\text { culture, urinalysis, X-rays, } \\
\text { abdominal ultrasound, } \\
\text { CT and MRCP: normal. } \\
\text { Serological study: } \\
\text { negative. Hepatic biopsy: } \\
\text { acute cholangitis. }\end{array}$ & $\begin{array}{c}\text { Acute } \\
\text { cholangitis }\end{array}$ \\
\hline $\begin{array}{c}\text { Mancano } \\
\text { et al., 2015 } \\
{[49]}\end{array}$ & 42 & W & $\begin{array}{c}\text { Garcinia } \\
\text { cambogia pure }\end{array}$ & 1 week & $\begin{array}{l}\text { Right upper } \\
\text { quadrant abdominal } \\
\text { pain and nausea } \\
\text { (without emesis). }\end{array}$ & $\begin{array}{l}\text { Laboratory analysis: } \\
\text { elevated ALT, AST, AF, } \\
\text { ferritin and INR } \\
\text { Serological study: } \\
\text { negative. Abdominal } \\
\text { ultrasound: normal. }\end{array}$ & Acute hepatitis \\
\hline $\begin{array}{l}\text { Melendez- } \\
\text { Rosado et al., } \\
2015 \text { [50] }\end{array}$ & 42 & W & $\begin{array}{c}\text { Garcinia } \\
\text { cambogia pure }\end{array}$ & 1 week & $\begin{array}{l}\text { Abdominal pain in } \\
\text { the right upper } \\
\text { quadrant, nausea } \\
\text { without emesis and } \\
\text { clamminess. }\end{array}$ & $\begin{array}{l}\text { Laboratory analysis: } \\
\text { elevated ALT, AST, AF } \\
\text { and ferritin. Serological } \\
\text { study: negative. } \\
\text { Abdominal ultrasound: } \\
\text { mildy coarse hepatic } \\
\text { echotexture. CT: normal. }\end{array}$ & Acute hepatitis \\
\hline
\end{tabular}


Table 2. Cont.

\begin{tabular}{|c|c|c|c|c|c|c|c|}
\hline Reference & Ageyears & Sex & $\begin{array}{c}\text { Type of } \\
\text { Supplement }\end{array}$ & Duration & Symptoms & Test Performed & $\begin{array}{l}\text { Diagnosis/Type } \\
\text { of Liver Injury }\end{array}$ \\
\hline $\begin{array}{c}\text { Araujo et al., } \\
2015 \text { [51] }\end{array}$ & 41 & $\mathrm{M}$ & $\begin{array}{l}\text { Hydroxycut } \\
\text { SX-7 Clean } \\
\text { Sensory }^{\mathrm{TM}} \\
2 \text { capsules/day } \\
4 \text { times/week }\end{array}$ & 2 months & $\begin{array}{c}\text { Malaise, jaundice, } \\
\text { fatigue, nausea, } \\
\text { vomiting and } \\
\text { asterixis }\end{array}$ & $\begin{array}{l}\text { Physical examination: } \\
\text { jaundice and liver edge } \\
\text { percussed. Laboratory } \\
\text { analysis: elevated AST, } \\
\text { ALT, TB, DB, PT and } \\
\text { creatinine. Serological } \\
\text { study: negative. } \\
\text { Abdominal ultrasound: } \\
\text { increased liver } \\
\text { echogenicity and } \\
\text { liver length. } \\
\text { CIOMS/RUCAM: } 9\end{array}$ & $\begin{array}{c}\text { Acute } \\
\text { hepatocellular } \\
\text { liver injury }\end{array}$ \\
\hline $\begin{array}{l}\text { Smith et al., } \\
2016 \text { [52] }\end{array}$ & 26 & $\mathrm{M}$ & $\begin{array}{c}\text { Multi- } \\
\text { ingredient } \\
\text { protein } \\
\text { supplement } \\
\text { with Garcinia } \\
\text { cambogia }(70 \%) \text {. }\end{array}$ & 1 week & $\begin{array}{c}\text { Jaundice, fatigue and } \\
\text { asterixis. }\end{array}$ & $\begin{array}{c}\text { Laboratory analysis: } \\
\text { elevated ALT, AST, } \\
\text { AFand bilirubin. } \\
\text { Serological study: } \\
\text { negative. Hepatic biopsy: } \\
\text { liver necrosis. CIOMS: } 6\end{array}$ & $\begin{array}{l}\text { Hepatotoxicity } \\
\text { Liver trans- } \\
\text { plantation } \\
\text { required. }\end{array}$ \\
\hline $\begin{array}{l}\text { Corey et al., } \\
2016 \text { [53] }\end{array}$ & 52 & W & $\begin{array}{c}\text { Garcinia } \\
\text { cambogia } \\
\text { supplement: } \\
\text { Garcinia } \\
\text { cambogia } \\
\text { extract (936 } \\
\text { mg, } 60 \% \text { HCA), } \\
\text { calcium, } \\
\text { chromium, } \\
\text { potassium } \\
2 \text { capsules/d } \\
\text { (1000 mg/day) }\end{array}$ & 3.5 weeks & $\begin{array}{l}\text { Decreased appetite, } \\
\text { worsening fatigue, } \\
\text { and intermittent } \\
\text { confusion. }\end{array}$ & $\begin{array}{l}\text { Physical examination: } \\
\text { abdominal distention and } \\
\text { jaundice. Laboratory } \\
\text { analysis: elevated ALT, } \\
\text { AST, AF, TB, DB and INR, } \\
\text { and low platelet count. } \\
\text { CT: nodular liver } \\
\text { compatible with necrosis } \\
\text { and ascites. Serological } \\
\text { study: negative. Biopsy: } \\
\text { severe acute hepatitis } \\
\text { with necrosis and } \\
\text { parenchymal collapse. } \\
\text { MELD: it was evolving } \\
\text { until it reached a score of } \\
\text { 40. CIOMS: } 7\end{array}$ & $\begin{array}{l}\text { Acute liver } \\
\text { failure. Liver } \\
\text { transplanta- } \\
\text { tion } \\
\text { required. }\end{array}$ \\
\hline
\end{tabular}

Laboratory analysis: elevated transaminases and bilirubin. Asterixis, jaundice, and confusion. Elevated transaminases, bilirubin, elevated INR.

Images: cirrhosis or hepatocellular carcinoma. MR: no tumor process.Serological study: positive antinuclear antibody.Hepatic biopsy: necrosis with collapse of the liver architecture.

Laboratory analysis: ALT AST, TB, DB, albumin, AF, GGT out of normal range. Serological study: negative. Abdominal ultrasound, MRI. ANANAS

SLIM $^{\mathrm{TM}}$ :

Crescioli

et al., 2018

61

W

\section{Garcinia}

cambogia $(60 \%)$,

Ananas comosus

2 months

and Ilex

paraguariensis.
Abdominal pain, nausea, progressive weakness, jaundice, dark stools, and acholic stools.
Severe liver injury. Liver transplantation required.
Doppler: normal. CT: small peritoneal effusion and perihepatic lymphadenopathy. Biopsy: cholestatic hepatitis. CIOMS: 7. 
Table 2. Cont.

\begin{tabular}{|c|c|c|c|c|c|c|c|}
\hline Reference & Ageyears & Sex & $\begin{array}{c}\text { Type of } \\
\text { Supplement }\end{array}$ & Duration & Symptoms & Test Performed & $\begin{array}{l}\text { Diagnosis/Type } \\
\text { of Liver Injury }\end{array}$ \\
\hline $\begin{array}{c}\text { Crescioli } \\
\text { et al., } 2018 \\
\text { [55] }\end{array}$ & 39 & W & $\begin{array}{c}\text { Two } \\
\text { sipplements: } \\
\text { OBLESSTM: } \\
\text { Garcinia } \\
\text { cambogia }(72 \mathrm{mg} \\
\text { of HCA) and } \\
\text { other } \\
\text { components: } \\
1 \text { capsule/day } \\
\text { and } \\
\text { Magistral } \\
\text { preparation of } \\
\text { different herbs } \\
\text { extracts: } 1 \\
\text { capsule/day }\end{array}$ & 1 month & $\begin{array}{l}\text { Jaundice, asthenia, } \\
\text { loss of appetite, and } \\
\text { right hypochondrial } \\
\text { pain. }\end{array}$ & $\begin{array}{c}\text { Laboratory analysis: } \\
\text { elevated ALT, AST, TB, } \\
\text { DB, AF, GGT, CRP and } \\
\text { lactate dehydrogenase. } \\
\text { Serological study: } \\
\text { nonspecific antinuclear } \\
\text { antibodies and positive } \\
\text { bile antibodies. } \\
\text { Abdominal ultrasound: } \\
\text { normal. CIOMS: } 6\end{array}$ & $\begin{array}{c}\text { Acute } \\
\text { cholestatic }\end{array}$ \\
\hline $\begin{array}{c}\text { Crescioli } \\
\text { et al., } 2018 \\
\text { [55] }\end{array}$ & 47 & W & $\begin{array}{l}\text { THERMO } \\
\text { GIALLOTM: } \\
\text { Garcinia } \\
\text { cambogia (200 } \\
\text { mg HCA) and } \\
\text { chromium: y } 2 \\
\text { capsules/da. }\end{array}$ & 1 month & $\begin{array}{l}\text { Severe abdominal } \\
\text { pain. }\end{array}$ & $\begin{array}{c}\text { Laboratory analysis: } \\
\text { elevated AST, ALT and } \\
\text { TB. Serological study: } \\
\text { negative. } \\
\text { CIOMS: } 6 .\end{array}$ & $\begin{array}{c}\text { Acute } \\
\text { hepatitis. }\end{array}$ \\
\hline $\begin{array}{l}\text { Crescioli } \\
\text { et al., } 2018 \\
{[55]}\end{array}$ & 52 & W & $\begin{array}{l}2 \text { JILL COOPER } \\
\text { BE SLIMTM: } \\
\text { Garcinia } \\
\text { cambogia ( } 240 \\
\text { mg) and Green } \\
\text { Coffee extract } 1 \\
\text { capsule / d of } \\
\text { each product }\end{array}$ & 1 month & & $\begin{array}{l}\text { Laboratory analysis: } \\
\text { elevated AST, ALT, BT, } \\
\text { GGT and AF. Serological } \\
\text { test: negative. CIOMS: } 6 \text {. }\end{array}$ & $\begin{array}{c}\text { Acute } \\
\text { hepatitis. }\end{array}$ \\
\hline $\begin{array}{c}\text { Sharma } \\
\text { et al., 2018 } \\
\text { [56] }\end{array}$ & 57 & W & $\begin{array}{c}\text { Garcinia } \\
\text { cambogia }(100 \%) \\
\text { and vitamin A } \\
\text { and D } \\
\text { supplement } 2 \\
\text { capsules/d } \\
(2800 \mathrm{mg} / \mathrm{d})\end{array}$ & 1 month & $\begin{array}{l}\text { Abdominal pain } \\
\text { (more intense in the } \\
\text { right upper quadrant) } \\
\text { and vomiting. }\end{array}$ & $\begin{array}{l}\text { Laboratory analysis: } \\
\text { elevated ALT, AST, TB, } \\
\text { DB, INR, PT. Normal } \\
\text { vitamin A and D levels. } \\
\text { Serological study: } \\
\text { negative Abdominal } \\
\text { ultrasound: normal liver } \\
\text { CIOMS/RUCAM: } 11\end{array}$ & $\begin{array}{l}\text { Hepatitis } \\
\text { secondary to } \\
\text { the } \\
\text { consumption } \\
\text { of Garcinia } \\
\text { cambogia. After } \\
\text { withdrawal of } \\
\text { the supplement } \\
\text { the levels of } \\
\text { the altered } \\
\text { enzymes } \\
\text { normalized. } \\
\text { After six } \\
\text { months they } \\
\text { elevated again, } \\
\text { coinciding } \\
\text { with the } \\
\text { reintroduction } \\
\text { of the } \\
\text { supplement. }\end{array}$ \\
\hline
\end{tabular}


Table 2. Cont.

\begin{tabular}{|c|c|c|c|c|c|c|c|}
\hline Reference & Ageyears & Sex & $\begin{array}{c}\text { Type of } \\
\text { Supplement }\end{array}$ & Duration & Symptoms & Test Performed & $\begin{array}{l}\text { Diagnosis/Type } \\
\text { of Liver Injury }\end{array}$ \\
\hline $\begin{array}{c}\text { Philips } \\
\text { et al., } 2018 \\
{[57]}\end{array}$ & 33 & W & $\begin{array}{c}\text { Safe Lean }^{\mathrm{TM}} \text { : } \\
\text { Garcinia } \\
\text { cambogia }(600 \\
\text { mg), Allium } \\
\text { sativum }(250 \mathrm{mg}) \\
\text { and Trigonella } \\
\text { foenum graecum } \\
\text { (100 mg) } 1 \\
\text { capsule, } 2 \\
\text { times/day } \\
\text { Calcium, } \\
\text { vitamin A and } \\
\text { folic acid } \\
\text { supplement } 1 \\
\text { time/day }\end{array}$ & 3 months & $\begin{array}{c}\text { Nausea, loss of } \\
\text { appetite }\end{array}$ & $\begin{array}{c}\text { Laboratory analysis: } \\
\text { elevated AST, ALT, AF, } \\
\text { TB, gamma-glutamyl } \\
\text { transferase, albumin and } \\
\text { INR. Serological study: } \\
\text { negative. CT: } \\
\text { hepatomegaly. RUCAM: } \\
8\end{array}$ & $\begin{array}{l}\text { Drug induced } \\
\text { liver injury, } \\
\text { secondary to } \\
\text { Safe Lean }{ }^{\mathrm{TM}} \text {. }\end{array}$ \\
\hline $\begin{array}{l}\text { Yousaf et al., } \\
2019 \text { [58] }\end{array}$ & 21 & W & $\begin{array}{c}\text { Garcinia } \\
\text { cambogia } \\
1400 \mathrm{mg} / \text { day }\end{array}$ & 4 weeks & $\begin{array}{l}\text { Abdominal pain for } 1 \\
\text { wk associated with } \\
\text { nausea, vomiting, } \\
\text { anorexia and } \\
\text { myalgias. }\end{array}$ & $\begin{array}{l}\text { Abdominal ultrasound } \\
\text { Laboratory analysis: } \\
\text { elevated ALT, AST, } \\
\text { alkaline phosphatase }\end{array}$ & $\begin{array}{c}\text { Hepatomegaly } \\
\text { Acute liver } \\
\text { failure. }\end{array}$ \\
\hline $\begin{array}{c}\text { Khetpal } \\
\text { et al., } 2020 \\
\text { [59] }\end{array}$ & 22 & W & $\begin{array}{l}\text { Hydroxycut }^{\mathrm{TM}} 2 \\
\text { capsules/day }^{2}\end{array}$ & 3 months & $\begin{array}{l}\text { Chest pain, fatigue, } \\
\text { palpitations and } \\
\text { shortness of breath }\end{array}$ & $\begin{array}{c}\text { Physical examination: } \\
\text { tachycardia, low oxygen } \\
\text { saturation and asterixis. } \\
\text { Laboratory analysis: } \\
\text { elevated AST, ALT, INR, } \\
\text { leukocytes and white } \\
\text { blood cells. Serological } \\
\text { study: negative. } \\
\text { Abdominal ultrasound: } \\
\text { hepatomegaly. RUCAM: } \\
9 .\end{array}$ & $\begin{array}{c}\text { Acute } \\
\text { drug-induced } \\
\text { liver injury } \\
\text { likely due to } \\
\text { Hydroxycut }^{\mathrm{TM}} \text {. }\end{array}$ \\
\hline $\begin{array}{c}\text { Ferreira } \\
\text { et al., } 2020 \\
{[60]}\end{array}$ & 26 & W & $\begin{array}{l}1800 \text { mg of } \\
\text { Garcinia } \\
\text { cambogia ( } 900 \\
\text { mg HCA), } 1275 \\
\text { mg of green tea } \\
\text { extract with } 450 \\
\text { mg of Veldt } \\
\text { raisin and } 1200 \\
\text { mg of Coffea } \\
\text { arabica daily. }\end{array}$ & 7 months & $\begin{array}{l}\text { Fatigue, nausea and } \\
\text { jaundice. }\end{array}$ & $\begin{array}{c}\text { Laboratory analysis: } \\
\text { acute hepatitis (elevated } \\
\text { AST, ALT, TB and INR). } \\
\text { Abdominal Ultrasound: } \\
\text { normal. MRCP: normal. } \\
\text { Transjugular liver biopsy: } \\
\text { acute hepatitis. } \\
\text { Serological study: } \\
\text { negative. RUCAM: } 6 .\end{array}$ & $\begin{array}{l}\text { Subacute liver } \\
\text { failure } \\
\text { secondary to } \\
\text { the } \\
\text { consumption } \\
\text { of Garcinia } \\
\text { cambogia. Liver } \\
\text { transplanta- } \\
\text { tion } \\
\text { required. }\end{array}$ \\
\hline
\end{tabular}

M: men; W: women; ALT: alanine aminotransferase; AST: aspartate aminotransferase; AF: alkaline phosphatase; GGT: gamma-glutamyl transferase; TB: total bilirrubin; DB: direct bilirrubin; INR: international normalized ratio; PT: prothrombin time; CRP: C-reactive protein; CT: computed tomography; MRCP: magnetic resonance cholangiopancreatography; MR: magnetic resonance; CIOMS/RUCAM: scale for diagnosing drug-induced liver damage; MELD: scale to measure the severity of chronic liver disease. In cases where information about dose is not provided, it is because it was not indicated in the article.

The FDA warned consumers about the serious adverse effects associated with the consumption of Hydroxycut ${ }^{\mathrm{TM}}$. This recommendation was based on 23 cases of liver damage, including one death and a liver transplant. All this led to the withdrawal of the supplement from the market. Later on, García-Cortés et al. (2016) reported 29 cases of liver damage induced by this supplement [61].

Taking this into account, as it can observed in Table 2, hepatotoxic effects have also been reported when using pure Garcinia cambogia extracts $[49,50,54]$ or supplements that only contained Garcinia cambogia with minerals or vitamins $[53,55,56]$. The reason that justifies the occurrence of hepatotoxic effects in these cases, but not in all the studies gathered in Table 1, is not clear. Genetic interindividual variability leading to different susceptibility to the action of Garcinia cannot be ruled out. Nevertheless, it is important to emphasize that counting all the subjects that participated in the studies described in 
Table 1, the lack of toxic effects refers to a quite big sample, whereas toxic effects have only been described in a reduced number of subjects.

The common pattern of symptoms, observed in all these cases, consisted of abdominal pain (predominantly in the right upper quadrant), vomiting, nausea, fatigue and alterations in liver parameters such as transaminases, alkaline phosphatase and bilirubin. Serological tests were performed to rule out other possible causes of liver damage and/or infection, such as hepatitis, Epstein-Barr virus, cytomegalovirus, etc. In eight cases the CIOMS/RUCAM scale was used. This scale is a scoring system used to establish the etiology of drug-induced liver damage, and depending on the score obtained, the substance is classified as a highly probable cause ( $\geq 9)$, probable cause (6-8), possible cause (3-5), unlike cause (1-2) or excluded cause (0) of liver injury. The scores obtained for the supplements in these studies ranged from 6 to 11 points; in other words, probable to highly probable cause. Importantly, after Garcinia supplement withdrawal, the symptoms subsided and all the altered parameters returned to normal levels, although in four cases the patient finally required liver transplantation.

Regarding acute pancreatitis, one case has been reported in an 82-year-old man with past medical history of obesity and two previous episodes of acute pancreatitis in the past. He denied any alcohol use and reported no recent changes in his medications, as well as the intake of Garcinia cambogia recently as an appetite suppressant. He was treated with bowel rest and intravenous fluid hydration, providing a significant improvement in his symptoms [62].

Other adverse effects associated with Garcinia cambogia ingestion are mania and psychosis, as shown in Table 3 [63-66]. Nevertheless, currently the existing scientific evidence is limited and a causal association has not yet been established with certainty. In some cases, the participants had a previous psychiatric history and/or were treated with selective serotonin reuptake inhibitors (SSRI). HCA acts as a selective serotonin reuptake inhibitor, thus increasing serotonin levels and increasing the risk of toxicity due to this neurotransmitter $[63,66]$. The most relevant symptoms were irritability and agitation. After the withdrawal of the supplement, the symptoms remitted, and all the altered parameters returned to normal levels.

To conclude, another type of toxicity associated with the consumption of Garcinia cambogia can be observed in patients with pre-existing metabolic disorders. In this line, Bystrak et al. (2017) described the case of a 56-year-old insulin-dependent, hypertensive woman with chronic hepatitis $C$, who developed diabetic ketoacidosis, pancreatitis, and cardiomyopathic stress after consuming a Garcinia cambogia supplement (1400 mg HCA/day) to lose weight [67]. Applying the algorithm described by Naranjo et al. (1981) [68] to estimate the causality of an adverse drug reaction, a value of five was obtained, meaning a probable adverse reaction to the use of Garcinia cambogia [67].

Table 3. Cases of mania and serotonin toxicity associated with the intake of Garcinia cambogia supplements in humans.

\begin{tabular}{|c|c|c|c|c|c|c|c|}
\hline Reference & Ageyears & Sex & $\begin{array}{c}\text { Previous } \\
\text { Psychiatric } \\
\text { History }\end{array}$ & $\begin{array}{c}\text { Type of } \\
\text { Supplement and } \\
\text { Treatment } \\
\text { Duration }\end{array}$ & $\begin{array}{c}\text { Psychotropic/ } \\
\text { Antidepressant } \\
\text { Drugs }\end{array}$ & Symptoms & Diagnosis \\
\hline $\begin{array}{l}\text { Lopez et al., } \\
2014 \text { [63] }\end{array}$ & 35 & W & No & $\begin{array}{c}1000 \text { mg Garcinia } \\
\text { cambogia } \\
(60 \% \text { HCA }), \\
\text { chromium, } \\
\text { potassium and } \\
\text { calcium } 2 \text { capsules, } \\
3 \text { times / day. } 2-3 \\
\text { months. }\end{array}$ & $\begin{array}{l}\text { Yes: escitalopram } \\
\text { (SSRI). } 1 \text { year. }\end{array}$ & $\begin{array}{c}\text { Stuttering speech } \\
\text { pattern, } \\
\text { spontaneous } \\
\text { ankle clonus, } \\
\text { bilateral ocular } \\
\text { clonus, rhythmic } \\
\text { jaw movements, } \\
\text { profuse sweating, } \\
\text { hypertension, } \\
\text { tachycardia, and } \\
\text { hyperreflexia. }\end{array}$ & $\begin{array}{c}\text { Serotonin } \\
\text { toxicity } \\
\text { associated with } \\
\text { Garcinia } \\
\text { cambogia } \\
\text { ingestion. }\end{array}$ \\
\hline
\end{tabular}


Table 3. Cont.

\begin{tabular}{|c|c|c|c|c|c|c|c|}
\hline Reference & Ageyears & Sex & $\begin{array}{l}\text { Previous } \\
\text { Psychiatric } \\
\text { History }\end{array}$ & $\begin{array}{c}\text { Type of } \\
\text { Supplement and } \\
\text { Treatment } \\
\text { Duration }\end{array}$ & $\begin{array}{c}\text { Psychotropic/ } \\
\text { Antidepressant } \\
\text { Drugs }\end{array}$ & Symptoms & Diagnosis \\
\hline \multirow{3}{*}{$\begin{array}{l}\text { Hendrickson } \\
\text { et al., 2016 } \\
\text { [64] }\end{array}$} & 50 & M & $\begin{array}{l}\text { Type I bipolar } \\
\text { disorder }\end{array}$ & $\begin{array}{l}\text { Garcinia cambogia: } \\
2 \text { capsules/day. } 2 \\
\text { months. }\end{array}$ & $\begin{array}{l}\text { No: he had been } \\
\text { stable off } \\
\text { medications for } \\
6 \text { years. }\end{array}$ & $\begin{array}{l}\text { Irritability, } \\
\text { pressured speech, } \\
\text { grandiosity, } \\
\text { excessive } \\
\text { spending, } \\
\text { increased social } \\
\text { activity and } \\
\text { decreased need } \\
\text { for sleep. }\end{array}$ & $\begin{array}{c}\text { Bipolar I } \\
\text { disorder, } \\
\text { manic, severe. }\end{array}$ \\
\hline & 25 & M & No & $\begin{array}{l}\text { Garcinia cambogia: } \\
1-2 \text { capsules/day. } 2 \\
\text { months. }\end{array}$ & No & $\begin{array}{c}\text { Inflated } \\
\text { self-esteem, } \\
\text { grandiosity, } \\
\text { decreased need } \\
\text { for sleep, } \\
\text { increased activity, } \\
\text { excessive } \\
\text { spending, } \\
\text { pressured speech, } \\
\text { paranoia and } \\
\text { religious } \\
\text { delusions. }\end{array}$ & $\begin{array}{c}\text { Bipolar I } \\
\text { disorder, } \\
\text { manic, severe } \\
\text { with psychosis. }\end{array}$ \\
\hline & 34 & W & $\begin{array}{l}\text { Type II bipolar } \\
\text { disorder and } \\
\text { past } \\
\text { SSRI-induced } \\
\text { hypomania }\end{array}$ & $\begin{array}{l}\text { Garcinia cambogia } \\
\text { For } 1-2 \text { months. }\end{array}$ & $\begin{array}{l}\text { Yes: aripiprazole, } \\
\text { bupropion and } \\
\text { topiramate. }\end{array}$ & $\begin{array}{l}\text { Irritability, } \\
\text { pressured speech, } \\
\text { decreased need } \\
\text { for sleep and } \\
\text { agitation. }\end{array}$ & $\begin{array}{c}\text { Recurrence of } \\
\text { bipolar } \\
\text { disorder type } \\
\text { II, hypomania, } \\
\text { moderate. }\end{array}$ \\
\hline $\begin{array}{l}\text { Cotovio } \\
\text { et al., 2017 } \\
{[65]}\end{array}$ & 51 & W & $\begin{array}{l}\text { Type I bipolar } \\
\text { disorder }\end{array}$ & $\begin{array}{l}\text { Garcinia cambogia, } \\
\text { calcium, chromium } \\
\text { and potassium. }\end{array}$ & $\begin{array}{c}\text { Yes: paroxetine } \\
\text { (SSRI) and valproic } \\
\text { acid }\end{array}$ & $\begin{array}{c}\text { Irritability, } \\
\text { agitation, } \\
\text { increased energy } \\
\text { and decreased } \\
\text { need for sleep. }\end{array}$ & $\begin{array}{l}\text { Hypomanic } \\
\text { episode } \\
\text { associated with } \\
\text { ingestion of } \\
\text { Garcinia } \\
\text { cambogia. }\end{array}$ \\
\hline $\begin{array}{c}\text { Nguyen } \\
\text { et al., 2019 } \\
\text { [66] }\end{array}$ & 22 & W & No & $\begin{array}{l}\text { Garcinia cambogia } \\
\text { Plus }{ }^{\mathrm{TM}} \text { : } 500 \mathrm{mg} \\
\text { Garcinia cambogia } \\
\text { per capsule } \\
\text { (60\% HCA) } \\
1 \text { capsule/day } \\
\text { during de first } 5 \\
\text { days and then } 3 \\
\text { capsules/d during } \\
\text { the next } 5 \text { days. }\end{array}$ & No & $\begin{array}{l}\text { Expansive mood, } \\
\text { psychomotor } \\
\text { agitation, } \\
\text { disorganized and } \\
\text { pressured speech, } \\
\text { flight of ideas, } \\
\text { grandiosity, } \\
\text { delusions and } \\
\text { auditory } \\
\text { hallucinations. }\end{array}$ & $\begin{array}{l}\text { Mania and } \\
\text { psychosis } \\
\text { secondary to } \\
\text { Garcinia } \\
\text { cambogia } \\
\text { ingestion. }\end{array}$ \\
\hline
\end{tabular}

M: men; W: women; SSRI: selective serotonin reuptake inhibitor.

\section{Concluding Remarks}

The reported scientific literature shows that nutritional supplements based on Garcinia extracts are effective in just over half of the reported studies. In these cases, the supplements should not constitute a treatment per se but, they should represent complementary tools to the conventional treatment of excess body fat. Moreover, due to their positive effects on lipid and glycemic profile, these supplements could be useful for the management of the co-morbidities associated with obesity.

Garcinia-based supplements have been shown to be safe in numerous human experiments, but the growing number of cases that report significant adverse effects, mainly associated with liver damage, and to a lesser extent with serotonin toxicity and mania, may lead to reconsideration of the safety of them. Although very often HCA has been signaled as the main element responsible for the toxic effects of Garcinia supplements, it should be noted that the fruit of Garcinia cambogia, an important source of HCA, has been consumed for centuries in Southeast Asia and has been generally recognized as safe 
(GRAS) [69]. On the other hand, as explained before in this review, in many cases Garcinia supplements contain a great number of components. Consequently, the toxicity cannot be reliably attributable to Garcinia, and it is difficult to make conclusions without giving rise to doubts or objections. Furthermore, potential negative effects due to the combination of the Garcinia supplement with other dietary supplements included in the consumer diet, or even with several drugs, cannot be discarded.

Importantly, adverse effect case reports usually reflect the associations between the observed toxicity and the intake of the dietary supplement, rather than causality. These associations need to be rigorously examined and, if finally, the supplements are found to be the causative factors for the alterations observed, the true agents need to be firmly identified, along with the dose at which the negative effects are induced [69]. In this regard, an important problem in diagnosing the cause that produces the adverse effects, is that many people perceive these type of products as not harmful or as "natural" products, thus, they tend to forget to mention them when they are asked about the foods, beverages and medications that they have consumed. It is therefore likely, that there are more cases than those diagnosed, and consequently, the magnitude of the problem may be underestimated. When the dose administered or the exact content of HCA are not specified, it is not possible to identify whether the dose exceeds the value established as NOAEL. Another important aspect, is that the issue of obesity-related liver co-morbidities as a cause of liver alterations, has been poorly handled in toxic effect reports. Much more attention should be paid to obesity-associated liver diseases in the causality assessment of dietary supplements used for weight reduction [70].

In this scenario, more studies are needed to evaluate the efficacy and safety of these products, using larger sample sizes and longer follow-up periods. Finally, it should be pointed out that there are certain population groups in which the use of these supplements should be discouraged. This is the case for pregnant and lactating women. HCA can affect the production of fatty acids and cholesterol, and can directly influence the production of sterols and steroid hormones. Pregnancy is a time of extreme sensitivity to steroid hormones, therefore, these products are not recommended. In the case of childrenalthough it has not been possible to prove that they are dangerous- the advice is not to consume them in large doses and for long periods of time. On the other hand, the evolution of patients with mild depression or with occasional episodes of hypomania who consume Garcinia should be monitored, since their situation may worsen.

Author Contributions: Conceptualization, M.P.P., Writing-Original Draft Preparation, N.A.; WritingReview \& Editing, M.P.P. and R.M.G.; Funding Acquisition, M.P.P. All authors have read and agreed to the published version of the manuscript.

Funding: This study was funded by Instituto de Salud Carlos III (CIBERobn) under Grant CB12/03/30007 and University of the Basque Country under Grant GIU18-173.

Institutional Review Board Statement: Not applicable.

Informed Consent Statement: Not applicable.

Data Availability Statement: Not applicable.

Conflicts of Interest: The authors declare no conflict of interest.

\section{References}

1. The heavy burden of obesity and the economics of prevention. In The Heavy Burden of Obesity; OECD Publishing: Paris, France, 2019.

2. World Health Organization. Obesity. Preventing and Managing the Global Epidemic. In Report of a WHO Consultation on Obesity; WHO/NUT/NCD/981; WHO: Geneva, Switzerland, 1998.

3. Haber, S.; Awwad, O.; Phillips, A.; Park, A.; Pham, T. Garcinia cambogia for weight loss. Am. J. Health-Syst. Pharm. 2018, 75, 17-22. [CrossRef] [PubMed] 
4. Garcia-Alvarez, A.; Egan, B.; de Klein, S.; Dima, L.; Maggi, F.M.; Isoniemi, M.; Ribas-Barba, L.; Raats, M.M.; Meissner, E.M.; Badea, M.; et al. Usage of plant food supplements across six European countries: Findings from the PlantLIBRA consumer survey. PLoS ONE 2014, 9, 537. [CrossRef]

5. Hemshekhar, M.; Sunitha, K.; Santhosh, M.; Devaraja, S.; Kemparaju, K.; Vishwanath, B.; Niranjana, S.R.; Girish, K.S. An overview on genus garcinia: Phytochemical and therapeutical aspects. Phytochem. Rev. 2011, 10, 325-351. [CrossRef]

6. Chuah, L.O.; Ho, W.Y.; Beh, B.K.; Yeap, S.K. Updates on antiobesity effect of Garcinia Origin (-)-HCA. Evid. Based Complement. Altern. Med. 2013, 2013, 751658. [CrossRef]

7. Semwal, R.B.; Semwal, D.K.; Vermaak, I.; Viljoen, A. A comprehensive scientific overview of Garcinia cambogia. Fitoterapia 2015, 102, 134-148. [CrossRef]

8. Jena, B.S.; Jayaprakasha, G.K.; Singh, R.P.; Sakariah, K.K. Chemistry and biochemistry of (-)-hydroxycitric acid from Garcinia. J. Agric. Food Chem. 2002, 50, 10-22. [CrossRef] [PubMed]

9. Ishihara, K.; Oyaizu, S.; Onuki, K.; Lim, K.; Fushiki, T. Chronic (-)-Hydroxycitrate Administration Spares Carbohydrate Utilization and Promotes Lipid Oxidation during Exercise in Mice. J. Nutr. 2000, 130, 2990-2995. [CrossRef] [PubMed]

10. Greenwood, M.R.; Cleary, M.P.; Gruen, R.; Blasé, D.; Stern, J.S.; Triscari, J.; Sullivan, A.C. Effect of (-)-hydroxycitrate on development of obesity in the Zucker obese rat. Am. J. Physiol. Endocrinol. Metab. 1981, 240, 72-78. [CrossRef]

11. Leonhardt, M.; Langhans, W. Hydroxycitrate has long-term effects on feeding behavior, body weight regain and metabolism after body weight loss in male rats. J. Nutr. 2002, 132, 1977-1982. [CrossRef] [PubMed]

12. Saito, M.; Ueno, M.; Ogino, S.; Kubo, K.; Nagata, J.; Takeuchi, M. High dose of Garcinia cambogia is effective in suppressing fat accumulation in developing male Zucker obese rats, but highly toxic to the testis. Food Chem. Toxicol. 2005, 43, 411-419. [CrossRef]

13. Heymsfield, S.B.; Allison, D.B.; Vasselli, J.R.; Pietrobelli, A.; Greenfield, D.; Nunez, C. Garcinia cambogia (Hydroxycitric Acid) as a potential antiobesity agent: A randomized controlled trial. JAMA 1998, 280, 1596-1600. [CrossRef] [PubMed]

14. Mattes, R.D.; Bormann, L. Effects of (-)-hydroxycitric acid on appetitive variables. Physiol. Behav. 2000, 71, 87-94. [CrossRef]

15. Thom, E. A randomized, double-blind, placebo-controlled trial of a new weight-reducing agent of natural origin. J. Int. Med. Res. 2000, 28, 229-233. [CrossRef] [PubMed]

16. Kovacs, E.M.R.; Westerterp-Plantenga, M.S.; Saris, W.H.M. The effects of 2-week ingestion of (-)-hydroxycitrate and (-)hydroxycitrate combined with medium-chain triglycerides on satiety, fat oxidation, energy expenditure and body weight. Int. J. Obes. 2001, 25, 1087-1094. [CrossRef] [PubMed]

17. Kovacs, E.M.R.; Westerterp-Plantenga, M.S.; de Vries, M.; Brouns, F.; Saris, W.H.M. Effects of 2-week ingestion of (-)hydroxycitrate and (-)-hydroxycitrate combined with medium-chain triglycerides on satiety and food intake. Physiol. Behav. 2001, 74, 543-549. [CrossRef]

18. Hayamizu, K.; Ishii, Y.; Kaneko, I.; Shen, M.; Okuhara, Y.; Shigematsu, N.; Tomi, H.; Furuse, M.; Yoshino, G.; Shimasaki, H. Effects of Garcinia cambogia (Hydroxycitric Acid) on visceral fat accumulation: A double-blind, randomized, placebo-controlled trial. Curr. Ther. Res. 2003, 64, 551-567. [CrossRef]

19. Preuss, H.G.; Bagchi, D.; Bagchi, M.; Rao, C.V.S.; Satyanarayana, S.; Dey, D.K. Efficacy of a novel, natural extract of (-)hydroxycitric acid (HCA-SX) and a combination of HCA-SX, niacin-bound chromium and Gymnema sylvestre extract in weight management in human volunteers: A pilot study. Nutr. Res. 2004, 24, 45-58. [CrossRef]

20. Preuss, H.G.; Bagchi, D.; Bagchi, M.; Rao, C.V.S.; Dey, D.K.; Satyanarayana, S. Effects of a natural extract of (-)-hydroxycitric acid (HCA-SX) and a combination of HCA-SX plus niacin-bound chromium and Gymnema sylvestre extract on weight loss. Diabetes Obes. Metab. 2004, 6, 171-180. [CrossRef]

21. Roongpisuthipong, C.; Kantawan, R.; Roongpisuthipong, W. Reduction of adipose tissue and body weight: Effect of water soluble calcium hydroxycitrate in Garcinia atroviridis on the short term treatment of obese women in Thailand. Asia Pac. J. Clin. Nutr. 2007, 16, 25.

22. Toromanyan, E.; Aslanyan, G.; Amroyan, E.; Gabrielyan, E.; Panossian, A. Efficacy of Slim339®in reducing body weight of overweight and obese human subjects. Phytother. Res. 2007, 21, 1177-1181. [CrossRef]

23. Vasques, C.A.R.; Rossetto, S.; Halmenschlager, G.; Linden, R.; Heckler, E.; Fernandez, M.S.P.; Alonso, J.L.L. Evaluation of the pharmacotherapeutic efficacy of Garcinia cambogia plus Amorphophallus konjac for the treatment of obesity. Phytother. Res. 2008, 22, 1135-1140. [CrossRef] [PubMed]

24. Kim, J.; Jeon, S.; Park, K.H.; Lee, W.S.; Jeong, T.; McGregor, R.A.; Choi, M.-S. Does Glycine max leaves or Garcinia Cambogia promote weight-loss or lower plasma cholesterol in overweight individuals: A randomized control trial. Nutr. J. 2011, 10, 94. [CrossRef] [PubMed]

25. Lu, C.H.; Yang, T.H.; Wu, C.C.; Doong, J.Y.; Lin, P.Y.; Chiang, C.M.; Lin, C.L.; Hsieh, S.L. Clinical evaluation of Garcinia cambogia and Phaseolus vulgaris extract for obese adults in taiwan. Nutr. Sci. J. 2012, 37, 75-84. [CrossRef]

26. Stern, J.S.; Peerson, J.; Mishra, A.T.; Sadasiva Rao, M.V.; Rajeswari, K.P. Efficacy and tolerability of a novel herbal formulation for weight management. Obesity 2013, 21, 921-927. [CrossRef] [PubMed]

27. Stern, J.S.; Peerson, J.; Mishra, A.T.; Mathukumalli, V.S.R.; Konda, P.R. Efficacy and tolerability of an herbal formulation for weight management. J. Med. Food 2013, 16, 529-537. [CrossRef]

28. Chong, P.; Beah, Z.; Grube, B.; Riede, L. IQP-GC-101 reduces body weight and body fat mass: A randomized, double-blind, placebo-controlled study. Phytother. Res. 2014, 28, 1520-1526. [CrossRef] 
29. Vasques, C.A.R.; Schneider, R.; Klein-Júnior, L.C.; Falavigna, A.; Piazza, I.; Rossetto, S. Hypolipemic Effect of Garcinia cambogia in Obese Women. Phytother. Res. 2014, 28, 887-891. [CrossRef]

30. Kudiganti, V.; Kodur, R.R.; Kodur, S.R.; Halemane, M.; Deep, D.K. Efficacy and tolerability of Meratrim for weight management: A randomized, double-blind, placebo-controlled study in healthy overweight human subjects. Lipids Health Dis. 2016, 15, 136. [CrossRef]

31. Maia-Landim, A.; Ramírez, J.M.; Lancho, C.; Poblador, M.S.; Lancho, J.L. Long-term effects of Garcinia cambogia/Glucomannan on weight loss in people with obesity, PLIN4, FTO and Trp64Arg polymorphisms. BMC Complement. Altern. Med. 2018, 18, 26. [CrossRef]

32. Watanabe, M.; Gangitano, E.; Francomano, D.; Addessi, E.; Toscano, R.; Costantini, D.; Tuccinardi, D.; Mariani, S.; Basciani, S.; Spera, G.; et al. Mangosteen Extract shows a potent Insulin sensitizing effect in Obese female patients: A prospective randomized controlled pilot study. Nutrients 2018, 10, 586. [CrossRef]

33. Onakpoya, I.; Hung, S.K.; Perry, R.; Wider, B.; Ernst, E. The use of Garcinia extract (hydroxycitric acid) as a weight loss supplement: A systematic review and meta-analysis of randomised clinical trials. J. Obes. 2011, 2011, 509038. [CrossRef]

34. Chuah, L.O.; Yeap, S.K.; Ho, W.Y.; Beh, B.K.; Alitheen, N.B. In vitro and in vivo toxicity of Garcinia or hydroxycitric acid: A review. Evid. Based Complement. Altern. Med. 2012, 2012, 197920. [CrossRef]

35. Soni, M.G.; Burdock, G.A.; Preuss, H.G.; Stohs, S.J.; Ohia, S.E.; Bagchi, D. Safety assessment of (-)-hydroxycitric acid and Super CitriMax ${ }^{\circledR}$, a novel calcium/potassium salt. Food Chem. Toxicol. 2004, 42, 1513-1529. [CrossRef]

36. Márquez, F.; Babio, N.; Bulló, M.; Salas-Salvadó, J. Evaluation of the safety and efficacy of hydroxycitric acid or Garcinia cambogia extracts in humans. Crit. Rev. Food Sci. Nutr. 2012, 52, 585-594. [CrossRef]

37. Ohia, S.; Opere, C.; LeDay, A.; Bagchi, M.; Bagchi, D.; Stohs, S. Safety and mechanism of appetite suppression by a novel hydroxycitric acid extract (HCA-SX). Mol. Cell. Biochem. 2002, 238, 89-103. [CrossRef]

38. Clouatre, D.L.; Preuss, H.G. Hydroxycitric acid does not promote inflammation or liver toxicity. World J. Gastroenterol. 2013, 19, 8160-8162. [CrossRef]

39. Shara, M.; Ohia, S.E.; Yasmin, T.; Zardetto-Smith, A.; Kincaid, A.; Bagchi, M.; Chatterjee, A.; Bagchi, D.; Stohs, S.J. Dose- and time-dependent effects of a novel (-)-hydroxycitric acid extract on body weight, hepatic and testicular lipid peroxidation, DNA fragmentation and histopathological data over a period of 90 days. Mol. Cell. Biochem. 2003, 254, 339-346. [CrossRef]

40. Shara, M.; Ohia, S.E.; Schmidt, R.E.; Yasmin, T.; Zardetto-Smith, A.; Kincaid, A.; Bagchi, M.; Chatterjee, A.; Bagchi, D.; Stohs, S.J. Physico-chemical properties of a novel (-)-hydroxy- citric acid extract and its effect on body weight, selected organ weights, hepatic lipid peroxidation and DNA fragmentation, hematology and clinical chemistry, and histopathological changes over a period of 90 days. Mol. Cell. Biochem. 2004, 260, 171-186. [CrossRef]

41. Kim, Y.; Choi, M.; Park, Y.B.; Kim, S.R.; Lee, M.; Jung, U.J. Garcinia cambogia attenuates diet-induced adiposity but exacerbates hepatic collagen accumulation and inflammation. World J. Gastroenterol. 2013, 19, 4689-4701. [CrossRef]

42. Kothadia, J.P.; Kaminski, M.; Samant, H.; Olivera-Martinez, M. Hepatotoxicity associated with use of the weight loss supplement Garcinia cambogia: A case report and review of the literature. Case Rep. Hepatol. 2018, 2018, 6483605. [CrossRef]

43. Farombi, E.O.; Adedara, I.A.; Oyenihi, A.B.; Ekakitie, E.; Kehinde, S. Hepatic, testicular and spermatozoa antioxidant status in rats chronically treated with Garcinia kola seed. J. Ethnopharmacol. 2013, 146, 536-542. [CrossRef]

44. Saiyed, Z.M.; Sengupta, K.; Krishnaraju, A.V.; Trimurtulu, G.; Lau, F.C.; Lugo, J.P. Safety and toxicological evaluation of Meratrim ${ }^{\circledR}$ : An herbal formulation for weight management. Food Chem. Toxicol. 2015, 78, 122-129. [CrossRef]

45. Stevens, T.; Qadri, A.; Zein, N.N. Two patients with acute liver injury associated with use of the herbal weight-loss supplement hydroxycut. Ann. Intern. Med. 2005, 142, 477-478. [CrossRef]

46. Dara, L.; Hewett, J.; Lim, J.K. Hydroxycut hepatotoxicity: A case series and review of liver toxicity from herbal weight loss supplements. World J. Gastroenterol. 2008, 14, 6999-7004. [CrossRef]

47. Shuster, J. Priapism and risperidone; Psoriasis after certolizumab therapy; bruxism with two different SSRIs; Nasal septum deviation associated with bevacizumab treatment; Hepatic failure with another herbal weight loss supplement; Bupropion-related dystonia and parkinsonism; bendamustine-associated hemolytic anemia. Hosp. Pharm. 2010, 45, 100-109. [CrossRef]

48. Sharma, T.; Wong, L.; Tsai, N.; Wong, R.D. Hydroxycut $\left({ }^{\circledR}\right)$ (herbal weight loss supplement) induced hepatotoxicity: A case report and review of literature. Hawaii Med. J. 2010, 69, 188-190.

49. Mancano, M.A. Garcinia cambogia-Induced Acute Hepatitis; Varenicline-Induced Parkinsonism; Resistant Hypocalcemia after Zoledronic Acid Administration; Zonisamide-Induced Acute Kidney Injury; Psychosis Associated with Guanfacine. Hosp. Pharm. 2015, 50, 564-568. [CrossRef]

50. Melendez-Rosado, J.; Snipelisky, D.; Matcha, G.; Stancampiano, F. Acute hepatitis induced by pure Garcinia cambogia. J. Clin. Gastroenterol. 2015, 49, 449-450. [CrossRef]

51. Araujo, J.L.; Worman, H.J. Acute liver injury associated with a newer formulation of the herbal weight loss supplement Hydroxycut. BMJ Case Rep. 2015, 2015, bcr2015210303. [CrossRef]

52. Smith, R.J.; Bertilone, C.; Robertson, A.G. Fulminant liver failure and transplantation after use of dietary supplements. Med. J. Aust. 2016, 204, 30-32. [CrossRef]

53. Corey, R.; Werner, K.T.; Singer, A.; Moss, A.; Smith, M.; Noelting, J.; Rakela, J. Acute liver failure associated with Garcinia cambogia use. Ann. Hepatol. 2016, 15, 123. [CrossRef] 
54. Lunsford, K.E.; Bodzin, A.S.; Reino, D.C.; Wang, H.L.; Busuttil, R.W. Dangerous dietary supplements: Garcinia cambogia-associated hepatic failure requiring transplantation. World J. Gastroenterol. 2016, 22, 10071-10076. [CrossRef]

55. Crescioli, G.; Lombardi, N.; Bettiol, A.; Marconi, E.; Risaliti, F.; Bertoni, M.; Ippolito, F.M.; Maggini, V.; Gallo, E.; Firenzuoli, F.; et al. Acute liver injury following Garcinia cambogia weight-loss supplementation: Case series and literature review. Intern. Emerg. Med. 2018, 13, 857-872. [CrossRef]

56. Sharma, A.; Akagi, E.; Njie, A.; Goyal, S.; Arsene, C.; Krishnamoorthy, G.; Ehrinpreis, M. Acute hepatitis due to Garcinia cambogia extract, an herbal weight loss supplement. Case Rep. Gastrointest. Med. 2018, 2018, 9606171. [CrossRef]

57. Philips, C.A.; Augustine, P. Chemical analysis of weight loss herbal supplement safe lean ${ }^{\mathrm{TM}}$ associated with acute liver injury-A concern for spurious drug, misbranding and adulteration. J. Clin. Exp. Hepatol. 2018, 8, 471-473. [CrossRef]

58. Yousaf, M.N.; Chaudhary, F.S.; Hodanazari, S.M.; Sittambalam, C.D. Hepatotoxicity associated with Garcinia cambogia: A case report. World J. Hepatol. 2019, 11, 735-742. [CrossRef]

59. Khetpal, N.; Mandzhieva, B.; Shahid, S.; Khetpal, A.; Jain, A.G. Not All Herbals are Benign: A Case of Hydroxycut-induced Acute Liver Injury. Cureus 2020, 12, e6870. [CrossRef]

60. Ferreira, V.; Mathieu, A.; Soucy, G.; Giard, J.M.; Erard-Poinsot, D. Acute severe liver injury related to long-term Garcinia cambogia intake. ACG Case Rep. J. 2020, 7, e00429. [CrossRef]

61. García-Cortés, M.; Robles-Díaz, M.; Ortega-Alonso, A.; Medina-Caliz, I.; Andrade, R.J. Hepatotoxicity by dietary supplements: A tabular listing and clinical characteristics. Int. J. Mol. Sci. 2016, 17, 537. [CrossRef]

62. Iqbal, U.; Anwar, H.; Siddiqui, H.U.; Mehmood, A. Acute Pancreatitis Secondary to Use of Appetite Suppressant: Garcinia cambogia. Cureus 2019, 11, e4676. [CrossRef]

63. Lopez, A.; Kornegay, J.; Hendrickson, R. Serotonin toxicity associated with Garcinia cambogia over-the-counter supplement. J. Med. Toxicol. 2014, 10, 399-401. [CrossRef]

64. Hendrickson, B.P.; Shaikh, N.; Occhiogrosso, M.; Penzner, J.B. Mania induced by Garcinia cambogia: A case series. Prim. Care Companion CNS Disord. 2016, 18. [CrossRef]

65. Cotovio, G.; Oliveira-Maia, A.J. Hypomania induced by a Garcinia cambogia supplement. Aust. N. Z. J. Psychiatry 2017, 51, 641-642. [CrossRef]

66. Nguyen, D.C.; Timmer, T.K.; Davison, B.C.; McGrane, I.R. Possible Garcinia cambogia-induced mania with psychosis: A case report. J. Pharm. Pract. 2019, 32, 99-102. [CrossRef]

67. Bystrak, T.; Cervera-Hernandez, M.E.; Reddy, N.; King, Z.; Bratberg, J. Garcinia cambogia, Diabetic Ketoacidosis, and Pancreatitis. RI Med. J. 2017, 100, 48-50.

68. Naranjo, C.A.; Busto, U.; Sellers, E.M.; Sandor, P.; Ruiz, I.; Roberts, E.A.; Janecek, E.; Domecq, C.; Greenblatt, D.J. A method for estimating the probability of adverse drug reactions. Clin. Pharmacol. Ther. 1981, 30, 239-245. [CrossRef]

69. Stohs, S.J.; Preuss, H.G.; Ohia, S.E.; Kaats, G.R.; Keen, C.L.; Williams, L.D.; Burdock, G.A. No evidence demonstrating hepatotoxicity associated with hydroxycitric acid. World J. Gastroenterol. 2009, 15, 4087-4089. [CrossRef]

70. Teschke, R.; Wolff, A.; Eickhoff, A.; Danan, G. Is obesity rather than the dietary supplement used for weight reduction the cause of liver injury? JGH Open 2018, 2, 152-157. [CrossRef] 